Portland State University

PDXScholar

$1-1-2011$

\title{
Aberdeen and the Reformation: Implementation and Interpretation of Reform
}

Catherine Elizabeth McMillan

Portland State University

Follow this and additional works at: https://pdxscholar.library.pdx.edu/open_access_etds Let us know how access to this document benefits you.

Recommended Citation

McMillan, Catherine Elizabeth, "Aberdeen and the Reformation: Implementation and Interpretation of Reform" (2011). Dissertations and Theses. Paper 711.

https://doi.org/10.15760/etd.711

This Thesis is brought to you for free and open access. It has been accepted for inclusion in Dissertations and Theses by an authorized administrator of PDXScholar. Please contact us if we can make this document more accessible: pdxscholar@pdx.edu. 


\begin{abstract}
Aberdeen and the Reformation:
Implementation and Interpretation of Reform
\end{abstract}

by

Catherine Elizabeth MMㅗllan

A thesis submitted in partial fulfillment of the requirements for the degree of

\title{
Master of Arts
}

in

History

Thesis Committee:

Caroline Litzenberger, Chair

John Ott

Jennifer Schuberth

Thomas Luckett

Portland State University

(C)2011 


\begin{abstract}
In the burgh of Aberdeen in northeast Scotland, the realm's Reformation of 1559-1560 and the subsequent alteration of the religious landscape were unwelcome developments. Although national authorities required reform, the burgh's powerful governing local oligarchy, mainly comprised of wealthy Catholic burgesses, dictated the speed and shape of conformity to the new religion. Existing scholarship on Aberdeen in the 1560s has concentrated on the ways in which Aberdeen's leaders responded to the Reformation rather than the reasons behind those responses. Thus, the purpose of this thesis is to further the understanding of the implementation and interpretation of the Reformation and Reformed Protestantism in Aberdeen from c.
\end{abstract} 1560 to 1568 .

Aberdeen's town council records from 1559 to 1568 and kirk session legislation from 1562-1563 and 1568 are the foundational primary sources for this study. Close textual analysis makes visible the many layers of meaning contained within these sources and unearths the common threads that run throughout. Additional primary sources, such Confession of Faith, Book of Discipline, and relevant entries from the records of St Andrews' kirk session, serve to place Aberdeen in the larger national context and, in many aspects, highlight the burgh's comparative religious conservatism. 
Chapter One of this thesis provides an overview of the national political and religious history from the early 1540 s to the early 1570 s. Chapter Two focuses on Aberdeen's response to the Reformation Crisis of 1559-1560 and the subsequent implementation of reform from 1560 to 1568 as administered by the burgh's civic authorities. Finally, Chapter Three explores and explains the interpretation of the Reformation and Reformed Protestantism by the town council and the kirk session.

This thesis concludes that the town council of Aberdeen deftly maneuvered through the twists and turns of the Reformation and its immediate aftermath and was successful not only in retaining relative local autonomy, but also in restricting the pace and determining the character of reform. Furthermore, the burgh's kirk session sought common ground between Catholicism and Reformed Protestantism in doctrine and discipline and was able to distract attention from matters of religious belief and practice by concentrating on the regulation of moral behavior. 
Dedication

For Buckley 


\section{Acknowledgements}

What a delight it is to reflect on the knowledgeable help, thoughtful guidance, and generous support that I have received over the course of this thesis. My deepest appreciation and gratitude are first and foremost extended to my advisor, Dr. Caroline Litzenberger, whose remarkable command of and insights into early modern British history expand and enlighten my own comprehension and understanding. Furthermore, her rigorous standards for graduate work have sharpened my ability to study, analyze, and inform. The intelligence, wit, and demanding curriculum of Dr. John Ott have likewise contributed to my advancement as a student of medieval European religion. This thesis has also greatly benefitted from the recommendations of Dr. Jennifer Schuberth and Dr. Thomas Luckett.

Copies of the manuscript sources used for this study were obtained through the valuable efforts of Stella Fraser at the Aberdeen City and Aberdeenshire Archives and Robin Urquhart at the The National Archives of Scotland, who also kindly assisted me in deciphering the more-troublesome passages of Aberdeen's kirk session records. I am also thankful to the staff at Portland State University Library who handled my requests for a multitude of books and other materials.

The opportunities to serve as a graduate assistant for the History Department and graduate mentor for University Studies made my experience at Portland State University all the more valuable and rewarding. The magnanimous award provided by 
the Lauren Banasky Scholarship for Graduate Research in History enabled my research expedition to Scotland. The recognition and funding granted by Phi Alpha Theta allowed me to present at the Phi Alpha Theta Regional Conference.

I am much obliged to my friends and family who furnish unconditional support, encouragement, and amusement. It is from my parents that I learn the meaning and worth of erudition. 


\section{Table of Contents}

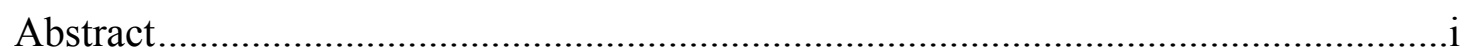

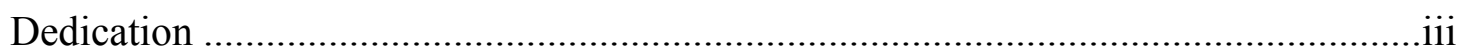

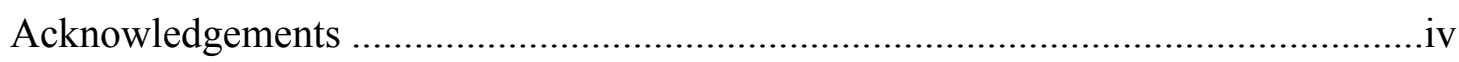

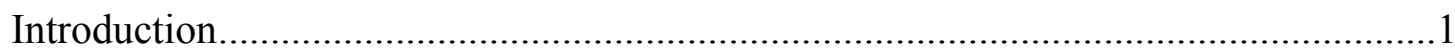

Chapter One

From "Wonderyear" to Civil War ............................................................................... 14

Chapter Two

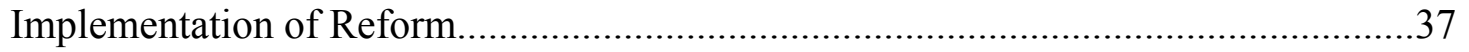

Chapter Three

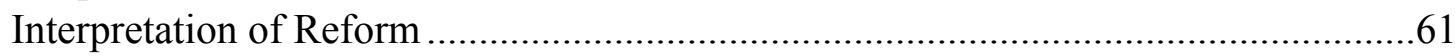

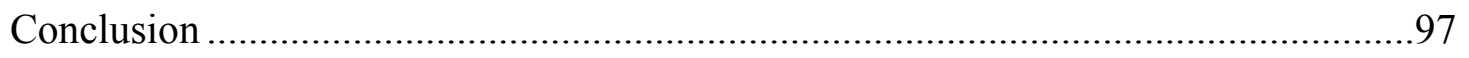

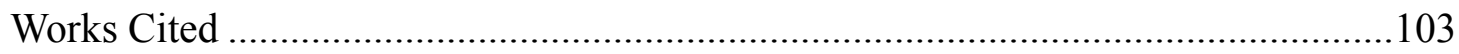




\section{Introduction}

On 17 August 1560, the Roman Catholic Church, which had had a presence in Scotland from the fifth century, was formally overthrown by the realm's parliament. ${ }^{1}$ In its place, a Reformed Protestant Confession of Faith was adopted and work began to establish a new Scottish Kirk. ${ }^{2}$ Acceptance of this Reformed Kirk and its attendant religious practices was uneven and there was significant regional differentiation. On the whole, Protestantism found more initial and lasting success in the Lowlands and faced continued resistance in the Highlands. ${ }^{3}$ Still, even in the Lowlands, acceptance varied from region to region. The localities of Dundee and St. Andrews, for example, were early Protestant outposts, while Edinburgh proceeded to implement a cautious Protestant agenda. ${ }^{4}$ Nonetheless, the base of the Reformation and Reformed Protestantism in Scotland lay in the south. ${ }^{5}$

In the northern burgh of Aberdeen, the Reformation and the subsequent alteration of the religious landscape were unwelcome developments. The burgh was a Catholic stronghold from the outset of religious rebellion in the spring of 1559 and only joined the Protestant Lords of the Congregation reluctantly in March 1560 when

\footnotetext{
${ }^{1}$ For ratification, see A1560/8/3, The Records of the Parliaments of Scotland to 1707, K.M. Brown et al eds (St Andrews, 2007-2011), http://www.rps.ac.uk/trans/A1567/12/18, downloaded 4/30/11; for evidence of Christianity, see J. Wormald, ed., Scotland: A History (Oxford: Oxford University, 2005), 351 .

${ }^{2}$ Michael F. Graham, The Uses of Reform: 'Godly Discipline' and Popular Behavior in Scotland and Beyond, 1560-1610 (Leiden: E. J. Brill, 1996), 35.

${ }^{3}$ Graham, 32.

${ }^{4}$ Graham, 49, 51, 77.

5 Graham, 32.
} 
it became clear that aligning with the Congregation was a political necessity. ${ }^{6}$ Yet those who governed the burgh, effectively a small oligarchy mainly comprised of wealthy Catholic burgesses, dictated the speed and shape of conformity to the new religion. ${ }^{7}$ Indeed, the burgh's kirk session, a disciplinary body required by the General Assembly, was not established until 1562 and its establishment was primarily driven by a desire to evince conformity to the visiting royal party. ${ }^{8}$ At the end of 1568 , Aberdeen remained Catholic in many, if not most, respects, although there were some meaningful, if limited, developments towards adopting comprehensive Protestantism.

Although the subject of the Reformation in Aberdeen has been included in the numerous works covering the Scottish Reformation as a whole, there are comparatively few studies dedicated to in-depth exploration of the burgh in the immediate years following the Reformation Crisis of 1559-1560. Furthermore, existing scholarship has concentrated on the ways in which Aberdeen's leaders responded to the Reformation rather than the reasons behind those responses. Thus, the purpose of this thesis is to further the understanding of the implementation and interpretation of the Reformation and Reformed Protestantism in Aberdeen from c. 1560 to 1568 .

Since Aberdeen was set apart from other localities in its religious and political conservatism, a brief summary of other burghs' experiences is merited in order to

\footnotetext{
${ }^{6}$ Graham, 59.

${ }^{7}$ Allan White, "Religion, Politics and Society in Aberdeen, 1543-1593" (PhD diss., University of Edinburgh, 1985), 3.

${ }^{8}$ White, "Religion, Politics and Society in Aberdeen," 203, 223.
} 
provide some comparison. As Jane Dawson observes in her study of St. Andrews, a Reformed church was established there in a matter of days in June 1559, a full year ahead of the rest of the realm. ${ }^{9}$ Through the support of local high-ranking lords and the burgh's inhabitants, the centuries-old ecclesiastical capitol of the Catholic Church in Scotland was transformed into the heart of the Reformed Kirk in just a few years. ${ }^{10}$ Furthermore, every aspect of the new kirk of St. Andrews served as a model and a template for other parishes, although most did not experience such rapid transition. ${ }^{11}$ In contrast to St. Andrews, Edinburgh's hesitation in adopting Protestantism during the Crisis was a result of concern over the political ramifications of taking a side. ${ }^{12}$ After the Reformation, Michael Lynch argues that the burgh remained conservative in many respects and was deeply attached to its localist mentality. ${ }^{13}$ Its Protestantism, Lynch maintains, was primarily the result of external forces, namely the religious leaders of the Reformation who took up residence in the city and the Protestants at court and in parliament. ${ }^{14}$ Although the experiences of St. Andrews and Edinburgh are much more complex than can be discussed here, these examples give a glimpse into the diversity of the Scottish Reformation. Concerning Aberdeen, its

\footnotetext{
9 Jane E. A. Dawson, "'The Face of Ane Perfyt Reformed Kyrk': St Andrews and the Early Scottish Reformation," in Humanism and Reform: The Church in Europe, England and Scotland 1400-1643: Essays in Honour of James K. Cameron, eds. James K. Cameron and James Kirk (Oxford: Blackwell, 1991), 415.

${ }^{10}$ Dawson, "'Ane Perfyt Reformed Kyrk,"' 414.

11 Dawson, "'Ane Perfyt Reformed Kyrk,"' 413.

12 Michael Lynch, Edinburgh and the Reformation (Edinburgh: John Donald Publishers, 1981), 7-8.

${ }^{13}$ Lynch, Edinburgh, 3.

${ }^{14}$ Lynch, Edinburgh, 7-8.
} 
deep-seated religious conservatism, economic vitality, stable and powerful oligarchy of burgesses, and heavily-uneven social composition contributed to its slow and stubborn Reformation.

Given that Aberdeen's deeply-embedded Catholicism was unique compared to other significant burghs, the majority of the questions that this study will address regard Aberdeen's approach to Reformed Protestantism and how it maintained a balance between the execution of that approach and the expectations and stipulations of the national Kirk, parliament, and the ruling elite. Regarding the implementation of Protestantism, the questions revolve around what the burgh's authorities chose to implement, and when and why certain measures were implemented. Essentially, what were the internal and external forces and circumstances that drove or impeded reform?

The fundamental question for the purposes of this thesis is how and why the burgh adopted Protestantism while retaining its Catholic core. Or, put another way, in what ways were the burgh's authorities able to infuse Catholic practices into the Protestantism that was now required by law? Were there some elements of the new Kirk that they accepted on a more fundamental level and, if so, why? When and where changes were put into action by Aberdeen's authorities, the records indicate, in many cases, a rebranding of Catholic principles, beliefs, and practices into an acceptable version of Protestantism. In what ways was this rebranding done? Finally, how did the religious landscape in Aberdeen differ in 1568 as compared to $1560 ?$ 
Before discussing the historiography of the Reformation and Aberdeen, the chosen timeframe merits a brief explanation. 1560 is the logical starting point given the events described above. The reasoning behind the end point of 1568 is, perhaps, not as clear, as it marked neither the beginning nor the end of the Civil Wars. It did, however, witness the fleeing of Queen Mary into England and a tilting of power in favor of James VI's supporters, which will be discussed in more detail in Chapter One. More importantly, Aberdeen's kirk session, defunct from January 1563, was reestablished in the spring of 1568, and its records give a glimpse into the religious and political circumstances of the time. Thus, the interval between 1560 and 1568 is a consequential but manageable timeframe for the purposes of this thesis.

Compared with the English Reformation and the various European reformations, the Scottish Reformation has not received as much attention from scholars as it deserves. Furthermore, as Alec Ryrie observed in 2006, the majority of histories that have been written on the subject, from John Knox's History of the Reformation in Scotland to David Hay Flemming's work The Reformation in Scotland, published in 1910, have been underpinned with a strong, often overriding, Protestant bias that has largely obscured the reality of a complex and woolly era. ${ }^{15}$ Additionally, as John McCallum noted as recently as 2010, the Reformation is often thought of as complete by the end of 1560 , whereas the events of that year merely set in motion a

\footnotetext{
${ }^{15}$ Alec Ryrie, The Origins of the Scottish Reformation (Manchester: Manchester University Press, 2006), 4, 5-6.
} 
process that would take decades to accomplish. ${ }^{16}$ The research of this thesis indicates that, among the works on Scottish history, the early 1560s itself is often an overlooked period, as scholarly attention swiftly shifts from the Reformation Crisis to the Civil Wars. ${ }^{17}$ One of the most likely causes of this gap in scholarship is the relative dearth of surviving sources. Indeed, it is only from the early seventeenth century that anything approaching a robust number of sources is available. Nonetheless, there are enough sources to warrant attention and, thus, this thesis will reach into the brambles of the 1560 s and bring the period into a brighter light.

As scholars are now devoting consideration to the immediate years following the Reformation, dedicated local Scottish histories have been a fairly recent development as well. In addition to Jane Dawson's and Michael Lynch's studies of St Andrews and Edinburgh, notable examples of this category include the scholars Frank Bardgett, Margaret Sanderson, Mary Verschuur, and John McCallum, who have covered Angus and the Mearns, Ayrshire, Perth, and Fife, respectively. ${ }^{18}$ Regarding Aberdeen, the doctoral dissertation and various articles written by Allan White and the collection of studies that comprise Aberdeen Before 1800: A New History (2002) form

\footnotetext{
${ }^{16}$ John McCallum, Reforming the Scottish Parish: the Reformation in Fife, 1560-1640 (Farnham: Ashgate, 2010), 1.

${ }^{17}$ Michael Lynch argues that "The cult of personality—of John Knox, Mary, Queen of Scots, and all that - has had the...effect of chopping Scotland's history into a series of dramatic turning-points, often bestrewn with a good deal of blood or melodrama." See Michael Lynch, Scotland: A New History (London: PIMLICO, 1992), xvii.

${ }^{18}$ Frank D. Bardgett, Scotland Reformed: the Reformation in Angus and the Mearns (Edinburgh: J. Donald Publishers, 1989); Margaret H. B. Sanderson, Ayrshire and the Reformation: People and Change, 1490-1600 (East Linton: Tuckwell Press, 1997); Mary Verschuur, Politics or religion?: The Reformation in Perth, 1540-1570 (Edinburgh: Dunedin Academic, 2006); McCallum, Reforming the Scottish Parish.
} 
a good portion of the basis for modern scholarship. Indeed, in the preface to Aberdeen Before 1800, the editors emphasize that the publication was the first extensive survey of the city's history since William Kennedy's examination, Annals of Aberdeen from the Reign of King William the Lion to the End of 1818 (1818). ${ }^{19}$ As mentioned above, however, these works, while thorough, aim primarily to provide a narrative of an extensive range of time. Allan White's dissertation, which covers religion, politics and society from 1543 to 1593 , is the most thorough and is a valuable and important secondary source for this research. Nonetheless, this study, particularly the third chapter, furthers the examination of Aberdeen's religion in the 1560 s as discussed by White by closely analyzing the components, religious and political, that governed the implementation and interpretation of reform.

Despite the paucity of dedicated scholarship, other works which survey a number of localities have successfully incorporated Aberdeen. The two that this thesis draws the most from are Michael F. Graham's The Uses of Reform: 'Godly Discipline' and Popular Behavior in Scotland and Beyond, 1560-1610 (1996) and Margo Todd's The Culture of Protestantism in Early Modern Scotland (2002). These excellent and thorough works inform this study with analyses of the roots below the actions and events of those who managed the roll-out of the reforms prescribed by the General Assembly, parliament, the monarchy, and the ruling elite. Furthermore, their findings

\footnotetext{
${ }^{19}$ E. Patricia Dennison, David Ditchburn, and Michael Lynch, preface to Aberdeen Before 1800: A New History, eds. E. Patricia Dennison, David Ditchburn, and Michael Lynch (East Linton: Tuckwell, 2002), xxvii-xxviii.
} 
help flesh out our knowledge of how ordinary people responded to the agenda imposed upon them and the ways in which they contributed to change or continuity.

The existing primary sources used for this thesis generally derive from two categories: secular and religious institutions. The secular sources include documents issued by parliament and the central government, although it is Aberdeen's civic records that are of the most concern. These records chronicle the day-to-day governance of the city, including council proclamations and notes, court cases, business relating to the finances of the churches of St. Nicholas and St. Machar, and property administration, among many other matters. For the purposes of this thesis, the council records trace Aberdeen's actions during the Reformation and its aftermath and inform the implementation portion of this study.

Their drawbacks, however, are similar to those that accompany all civic records. Firstly, the entries are those of a finished product; the surrounding discussions and activities are not included. Secondly, they may not accurately reflect the reality given the often complex and convoluted nature of matters and the underlying motivations of a particular recorder. Thirdly, omissions or edits may have occurred, even though the manuscripts are extant as far as is known. Nonetheless, this thesis assumes that a moderately high degree of accuracy and completeness is likely given the importance of such records to the council and the fact that their accessibility was strictly limited to council members. 
In addition to secular records, this thesis employs a number of Kirk sources, including the Book of Discipline, which was written by Protestant divines in the spring of 1560, and parliamentary religious legislation, such as the Confession of Faith Ratification Act, but focuses on those records from Aberdeen's kirk session. Although primarily a disciplinary body, the kirk session also dealt with matters of religious doctrine and worship. The initial entries in the session records, in particular, reflect these concerns. For example, the first entry from November 1562 begins with a lengthy explanation of the purpose of the session, namely to enforce God's word and will. Given that the session was comprised primarily of Catholics (crypto- or otherwise), "God's word and will" bear a traditional Catholic interpretation. As the detailing of specific cases comprise the later entries of the records, the religious foundation remains and offers a window into the mindset of Aberdeen's civic and religious authorities.

Of course, one of the weaknesses of this type of record is that the full picture is not given, partly because of practicality and partly because the session members were careful to present an appearance that would be acceptable to the national Kirk and influential Protestants while maintaining a meaningful and useable record for themselves. Additionally, the session was only in operation approximately for four months in the 1560 s, so a continuous week-to-week or even a year-to-year narrative is not possible. However, this silence is telling in itself as it indicates the lack of enthusiasm and effort by the session members to toe a strict Protestant line, especially 
when compared to other major burghs, such as St. Andrews, that quickly established and maintained kirk sessions. ${ }^{20}$ Keeping in mind these strengths and weaknesses, the kirk session records serve as the basis of this study of the burgh's interpretation of the new religion and provide some insight into the ways in which the council reconciled Catholic and Protestant belief and practice. $^{21}$

As noted above, the surviving primary sources that directly relate to the Reformation in Aberdeen are relatively scarce. Despite this disadvantage, a meaningful and scholarly study is possible, as others have demonstrated. Modern historians of this era are indebted to the efforts of various nineteenth-century compilers and printers of primary documents, particularly the Spalding Club of Aberdeen. Although the printed sources are advantageous in many respects, they are generally comprised of extracts and do not represent the whole of a particular source. Thus, available manuscripts have supplemented the printed source material. The two primary sources that inform the greatest part of this study are the minutes from Aberdeen's town council, which are more or less extant from 1398, and Aberdeen's St. Nicholas Kirk Session records from 1562-1563 and 1568. Because the five volumes of the council records that cover the period under consideration are each comprised of

\footnotetext{
${ }^{20}$ Although the only surviving kirk session records from before 1562 are from St. Andrews, other sources from the period indicate that other major burghs also had established kirk sessions prior to 1562. See Graham, 37.

${ }^{21}$ It is important to note that the aim here is not to ascertain individual religious belief. Rather, previous studies have confirmed that Aberdeen as a community was staunchly Catholic before the Reformation and at least through the 1560s. Furthermore, this study regards the outward signs of religious belief, such as the numerous altars housed in Aberdeen's St. Nicholas Kirk and their attendant rituals, as reasonably indicative of internal belief. For a critical examination of the connection between ritual and belief, see Catherine Bell, Ritual Theory, Ritual Practice (Oxford: Oxford University, 1992).
} 
600-900 pages and are only available through the Aberdeen City Council, an

exhaustive exploration of these sources has not been possible for this study. However, key selections of the council records have been obtained and contribute to the research of implementation as discussed in Chapter Two. The kirk session records have recently been digitized and made available online on a restricted basis through the National Archives of Scotland's Scottish Documents website. Therefore, this latter source has been studied in full and analyzed in Chapter Three.

The methodology employed in this study follows in the tradition of Reformation scholarship that views and understands history through the eyes of the sources rather than the lens of theory. ${ }^{22}$ Close textual analysis makes visible the many layers of meaning contained within the town council and kirk session records and unearths the common threads that run throughout. The surface of the town council records obviously exhibits the council's actions and often includes a brief explanation of the reason for an action. Generally not on display is the complex web of motivations and circumstances (such as political and religious) that underpin the actions, although fragments occasionally bubble up. This combination is compounded in the kirk session records because, unlike the council records, they were potentially subject to review by higher Kirk authorities. As such, it is clear that the session took

\footnotetext{
22 Examples of this tradition that have been used in this study include the works of the aforementioned Jane Dawson, John McCallum, and Margo Todd. See also Eamon Duffy, The Stripping of the Altars: Traditional Religion in England, c. 1400-c.1580 (New Haven: Yale University, 1992); Alexandra Walsham, Charitable Hatred: Tolerance and Intolerance in England, 1500-1700 (Manchester: Manchester University, 2006); Barbara D. Diefendorf, From Penitence to Charity (Oxford: Oxford University, 2004); Euan Cameron, The European Reformation (Oxford: Clarendon Press, 1991); Diarmaid MacCulloch, The Reformation (New York: Penguin, 2004).
} 
pains to ensure that the entries could pass muster with Kirk officials and simultaneously obliquely reflect the actual sentiments of the session. The session members' unwillingness to produce a register purely for show testifies to their respect for the process and indicates that they hedged their bets by producing legitimate and serviceable legislation so as not to be caught short in the event that the session became a permanent institution.

In order to place the focus of this thesis in the larger context of Scottish history, Chapter One provides an overview of the national political and religious history from the early 1540 s to the early 1570 s. Additionally, a discussion of the role of the regional magnates, the earls of Huntly, in national history furnishes an understanding of the external interests with which Aberdeen contended in its approach to reform. Chapter Two focuses on Aberdeen's response to the Reformation Crisis of 1559-1560 and the subsequent implementation of reform from 1560 to 1568 as administered by the burgh's civic authorities. Chapter Three explores and explains the interpretation of the Reformation and Reformed Protestantism by the town council and the kirk session, whose members were generally one and the same.

Finally, it is important to note that this thesis uses 1 January as the beginning of a new year, although it was not officially adopted as such in Scotland until the year $1600 .^{23}$ Additionally, because the language of sixteenth-century Scots employed in the

\footnotetext{
${ }^{23}$ C.R. Cheney, ed., A Handbook of Dates, For Students of British History, rev. ed. (Cambridge: Cambridge University, 2000), 14.
} 
written sources is often cumbersome to understand readily, the direct quotes from the sources provided in this thesis are translated into modern English. 


\section{Chapter One: From "Wonderyear" to Civil War}

By the sixteenth century, the settlement of greater Aberdeen had long been a hub of economic and political activity. ${ }^{24}$ Situated on the northeast coast of Scotland, its access to the North Sea helped establish strong trade links with Europe, and the two rivers that marked its boundaries connected it to its southern, western, and northern neighbors. ${ }^{25}$ However, it also benefitted from the relative isolation provided by the Grampian mountains and the hills of Mounth. Furthermore, the community "dominated the largest rural hinterland of any Scottish town." Therefore, it is no surprise that official medieval and early-modern sources describe Aberdeen as "the gateway to the 'north pairt' of the kingdom."26

The heart of the townscape of the southern burgh of New Aberdeen, which was granted royal burgh status during the reign of David I (1124-1153), was the market area of the Castlegate and its accompanying gathering places of the market cross, the tolbooth, and the tron. The tolbooth served a variety of purposes, including as the collection point of tolls or fees, courthouse, jail, and the meeting place for the town council. The burgh's castle once stood to the east of the Castlegate, but had been razed

\footnotetext{
${ }^{24}$ The immediate region of Aberdeen officially consisted of two settlements: Old Aberdeen to the north and New Aberdeen to the South. See E. Patricia Dennison, introduction to Aberdeen Before 1800: A New History, eds. E. Patricia Dennison, David Ditchburn, and Michael Lynch (East Linton: Tuckwell, 2002), 5 .

${ }^{25}$ Dennison, introduction to Aberdeen Before 1800, 1.

${ }^{26}$ Dennison, Ditchburn, and Lynch, preface to Aberdeen Before 1800, xxv.
} 
during the fourteenth century. Two mills were located to the west of the Castlegate. ${ }^{27}$ Surrounding the town's center were residential tofts, plots used for burgess housing and gardens in the back. As the burgh's population increased, the backlands were let to accommodate craft workshops and housing for the lower levels of society. ${ }^{28}$

Together, Old Aberdeen and New Aberdeen boasted an impressive number of ecclesiastical buildings. According to legend, the origins of Christianity in the settlement of what would become Old Aberdeen lie in the figure of St. Machar, a sixth-century associate of St. Columba himself who established a church at or near the site of the present day cathedral. ${ }^{29}$ By 1559 , the burgh and its environs exhibited all the physical hallmarks of a proud and distinguished Catholic community: St. Machar's Cathedral in Old Aberdeen, St. Nicholas Church and St. Maria ad Nives in New Aberdeen, four friaries, at least four chapels, a song school, three hospitals, King's College, and a handful of other ecclesiastical establishments. ${ }^{30}$ Although the existence of these religious buildings does not alone irrefutably evince the burgh's potent Catholicism, it is difficult to argue that moderate Catholicism would produce such an extensive number of richly-maintained establishments. At 246 feet long, St. Nicholas was Scotland's largest church in the sixteenth century and was ambitiously renovated

\footnotetext{
${ }^{27}$ E. Patricia Dennison, Anne T. Simpson, and Grant G. Simpson, "The Growth of the Two Towns," in Aberdeen Before 1800, eds. E. Patricia Dennison, David Ditchburn, and Michael Lynch (East Linton: Tuckwell, 2002), 23.

${ }^{28}$ Dennison, Simpson, and Simpson, "The Growth of the Two Towns," 18.

${ }^{29}$ Dennison, introduction to Aberdeen Before 1800, 10.

${ }^{30}$ Dennison, Simpson, and Simpson, "The Growth of the Two Towns," 23-27.
} 
in the latter half of the fifteenth century. ${ }^{31}$ Its thirty altars and fifty chantries are especially indicative of Catholic piety as each necessitated an expensive endowment. Thus, as Michael Lynch and Gordon DesBrisay have noted, the surviving architectural and documentary evidence testify to the "substantial investment in both the fabric of the burgh church and in chaplainries, obits and dedicated Masses within it almost from its foundation."32

Catholic clergy comprised a substantial portion of the region's population. It is likely that $25 \%$ of Old Aberdeen's adult population were clerics and $5 \%$ of $\mathrm{New}$ Aberdeen's adult male population were either priests, chaplains, or friars. ${ }^{33}$ Especially among the wealthier and politically-influential families, Church appointments also afforded employment opportunities for family members as benefactors often installed one of their own in clerical positions. For example, Robert Gray was chosen as chaplain of St. Barbara when his father endowed the chaplaincy in 1509. Nearly a half-century later, Gray's cousin assumed the role. ${ }^{34}$ Therefore, through the intricate kin networks, Aberdeen's lay residents were closely connected with the clergy and had spiritual as well as familial, political, and economic interests in the preservation of Catholicism.

\footnotetext{
31 Dennison, Ditchburn, and Lynch, preface to Aberdeen Before 1800, xxvi; Dennison, Simpson, and Simpson, "The Growth of the Two Towns," 23.

${ }^{32}$ Michael Lynch and Gordon DesBrisay, "The Faith of the People," in Aberdeen Before 1800: A New History, ed. E. Patricia Dennison, David Ditchburn, and Michael Lynch (East Linton: Tuckwell, 2002), 294.

33 Lynch and DesBrisay, "The Faith of the People," 289.

34 White, "Religion, Politics and Society in Aberdeen," 143.
} 
The political landscape of Aberdeen was equally impacted by kin ties.

Although the Gordons, sometime earls of Huntly, were the regional elite, control of the burgh rested in the hands of the merchant elite, which was consistently comprised more or less of a few dozen families. Not only did these families exercise immense economic control, but political control as well. Indeed, from 1560 to 1569 , all twentyseven town councillors to serve were elected from this elite group. ${ }^{35}$ The Menzieses were particularly powerful and rose to prominence through wealth, "administrative skill, astute political manoeuvering and a judicious scheme of alliance-building," which included a series of advantageous marriages. ${ }^{36}$ Their status enabled them to secure the top political offices for most of the sixteenth century. ${ }^{37}$ The most notable member of the family in the sixteenth century was Thomas Menzies, who succeeded his father as provost in 1525 and held the office for all but eleven years until his death 1576. ${ }^{38}$ Because the Menzieses and other burgess elite were "determined to preserve exclusive control of the town's governmental machinery," they were vigilant in checking the "predatory ambitions" of the local gentry and nobility and careful to maintain good relations with the crown, which acted as a counterweight to the regional magnates. ${ }^{39}$ Thus, this combination of powerful regional and local family dynasties

\footnotetext{
35 Allan White, "The Menzies Era: Sixteenth-Century Politics," in Aberdeen Before 1800: A New History, eds. E. Patricia Dennison, David Ditchburn, and Michael Lynch (East Linton: Tuckwell, 2002), 229.

${ }^{36}$ Allan White, "Impact of the Reformation on a Burgh Community: The Case of Aberdeen," in The Early Modern Town in Scotland, ed. Michael Lynch (Wolfeboro: Croom Helm, 1987), 82-83.

37 White, "The Menzies Era," 224.

38 White, "The Menzies Era," 225.

${ }^{39}$ White, "The Menzies Era," 224.
} 
ensured that northeastern Scotland was a formidable player in national affairs despite its isolation.

Of the major upheavals that impacted Aberdeen and the surrounding region throughout the sixteenth century, religion was a key factor in all. ${ }^{40}$ The first period of turbulence had ramifications that rippled for decades. After several years of unsuccessful efforts by Henry VIII of England (1509-1547) to convert James V of Scotland (1513-1542) to Henrician Catholicism, in part to secure England's northern border from international Catholic enemies, Henry VIII decided in 1542 to take and convert Scotland by force, which culminated in the battle of Solway Moss in November and the death of James V in December. ${ }^{41}$ As the six-day-old Mary (1542-1567) succeeded her father as reigning monarch, a battle for the regency ensued between David Beaton, Archbishop of St. Andrews, and James Hamilton, the second earl of Arran. ${ }^{42}$ By the end of January 1543, Arran had won the tussle and become the sole governor of Scotland. ${ }^{43}$

With Beaton neutralized, at least temporarily, and a great deal of the nobility in English captivity, Arran quickly sued for peace with Henry VIII and began pursuing an English-friendly agenda, which included arranging the marriage between Henry VIII's son Edward and Queen Mary and accepting English overlordship if Mary should die

\footnotetext{
${ }^{40}$ White, "The Menzies Era," 225.

${ }^{41}$ Ryrie, 55.

42 Jane E. A. Dawson, Scotland Re-formed, 1488-1587 (Edinburgh: Edinburgh University Press, 2007), 150 .

${ }^{43}$ Ryrie, 55.
} 
during her minority. ${ }^{44}$ The personal benefits of aligning with Henry VIII were great for Arran: in addition to having a tough defense against his Scottish opponents, ${ }^{45}$ Henry VIII dangled the prospect of a marriage between his daughter Elizabeth and Arran's son. More consequential for the nation as a whole, Arran was able to implement modest Protestant religious reforms, toward which he seems to have had genuine sympathies. ${ }^{46}$ Through the spring and summer of 1543, a handful of Protestant-friendly laws were passed by parliament, including allowing lay access to the vernacular Bible and limited public evangelical preaching by approved preachers. ${ }^{47}$ Furthermore, Arran discussed with the English ambassador the potential for the "dissolution of religious orders, the rejection of the papacy and the suppression of prayer for the dead."48 Although these reforms enacted during this "Wonderyear," as it has been termed, were tame in comparison with the objectives of die-hard Protestants, they did allow some breathing room for the pockets of Protestantism in the south and exposure of Protestant ideas to a wider audience. ${ }^{49}$

As a consequence of the peculiar and complex web of Scottish national politics at the time of James V's death, the ruling elite of Aberdeen suddenly found themselves being courted by the regent of Scotland in early 1543. Given the combination of the Gordons' Catholic and French loyalties, the Menzieses' ambitions to gain a presence in

\footnotetext{
${ }^{44}$ Ryrie, 55-56.

${ }^{45}$ Ryrie, 60.

${ }^{46}$ Ryrie, 57.

${ }^{47}$ Ryrie, $57-58$.

${ }^{48}$ Ryrie, 58.

${ }^{49}$ Ryrie, 64.
} 
national government, and Arran's need to have a foothold in the northeast in order to effect more fully his pro-English and pro-Protestant agenda and maintain a hold on the regency, Arran appointed Thomas Menzies, provost of Aberdeen, as comptroller and placed him on the government council in March 1543. ${ }^{50}$ Although it is unlikely that the Menzieses and the rest of the burgh's leading families had private leanings towards Protestantism, Thomas Menzies, with the support of the burgh council, furthered Arran's Protestant agenda, including allowing and even financing "two renegade Dominican friars" to preach openly the Protestant word. ${ }^{51}$ Through the spring and summer of 1543 , therefore, the Menzies family and their supporters were on the ascent in the national political arena.

In September 1543, however, Arran made a stunning "volte-face," which left the Menzieses and his other backers in the lurch. ${ }^{52}$ In the wake of the return from France of Arran's half-brother John Hamilton, the abbot of Paisley, in April 1543, the political rehabilitation of Archbishop Beaton and his newly-formed alliance with Mary of Guise, Queen Mary's French mother, and the increasingly untenable alliance with England, along with several other factors, Arran abandoned the pro-Protestant, proEnglish cause, reinstated heresy laws, and renewed the "auld alliance" with France. ${ }^{53}$ From September, Arran took up the "traditional royal policy of rule through the

\footnotetext{
50 White, "Impact of the Reformation on a Burgh Community," 84-85.

${ }^{51}$ White, "Impact of the Reformation on a Burgh Community," 85.

52 White, "Impact of the Reformation on a Burgh Community," 86.

53 Ryrie, 58-60, 67; Clare Kellar, Scotland, England, and the Reformation, 1534-61 (Oxford: Oxford University Press, 2003), 87-90.
} 
magnates," which included establishing friendly relations with George Gordon, fourth earl of Huntly, especially as Huntly had close ties with Beaton and supported the new scheme of contracting marriage between Arran's son and Queen Mary. ${ }^{54}$ As a result, Thomas Menzies was soon squeezed out of Arran's council and made to resign as comptroller. ${ }^{55}$ Furthermore, Huntly won the burgh's provost election in January 1545 and Menzies was made deputy provost. Menzies would manage to regain power in the council after Huntly was captured at the battle of Pinkie in September 1547, but his and his family's position was not firmly set until 1556, "when seats on the council became definitively hereditary." 56 The larger consequence of Aberdeen's brief support of Protestantism was that it calcified the burgh's religious and political conservatism and ultimately contributed to the burgh holding back from joining the Protestant cause during the Reformation Crisis of 1559-1560, and from fully complying with reform after the Protestant victory in July 1560, at the expense of gaining national political capital that may have eventually become a liability if Catholicism was restored. ${ }^{57}$

Henry VIII resumed the military campaign against Scotland in the spring of 1544 and Edward Seymour, who became Lord Protector after Henry VIII's death in January 1547 , led the English to a significant victory at Pinkie. ${ }^{58}$ However, major English logistical problems and the arrival of French troops sent by Henry II of France

\footnotetext{
54 White, "Impact of the Reformation on a Burgh Community," 86.

55 White, "Religion, Politics and Society in Aberdeen," 38.

56 White, "Impact of the Reformation on a Burgh Community," 86.

57 White, "Impact of the Reformation on a Burgh Community," 84.

58 Dawson, Scotland Re-formed, 168-169.
} 
(1519-1559) in June 1548 culminated in complete English defeat by the end of 1549.59 Surprisingly, Arran managed to retain the regency throughout this period and only resigned the position to Mary of Guise in $1554 .{ }^{60}$ Guise's attitude toward the multiplying pockets of Protestantism was one of tolerance and neutrality as she looked to balance Scottish Catholic and Protestant interests to ensure that Queen Mary would marry Dauphin Francis (1559-1560), as contracted by the 1548 Treaty of Haddington, and assume personal rule of Scotland. ${ }^{61}$

However, the increasing presence of French troops and the easing out of Scots from the highest ranks of government office resulted in widespread and virulent antiFrench sentiment. ${ }^{62}$ At the same time, a group of Scottish nobles, spurred on by the rhetoric of John Knox and other reformers, formed the First Band of the Lords of the Congregation in December 1557, modestly calling for the legalization of private Protestant preaching and the reading in local churches of "'the Common Prayers' and extracts from the Bible...using the English prayer books of Edward VI" of England. ${ }^{63}$ Despite its repeated petitions, the Congregation did not initially pose much of a threat to Mary of Guise.

However, a series of events in 1558 prompted her to crack down on all Protestant activities. Firstly, Queen Mary married Dauphin Francis in France in April

\footnotetext{
${ }^{59}$ Dawson, Scotland Re-formed, 172; Ryrie, 73-74.

${ }^{60}$ Dawson, Scotland Re-formed, 179.

${ }^{61}$ Dawson, Scotland Re-formed, 173; Kellar, 140.

${ }^{62}$ Ryrie, 142; Kellar, 140.

${ }^{63}$ Ryrie, 149.
} 
and the Scottish parliament granted Francis the crown matrimonial in November, thus removing a major concern of Mary of Guise. ${ }^{64}$ Secondly, a violent attack in Edinburgh by a group radical Protestants on the participants of the St. Giles Day procession was taken as an "act of terrorism" by Mary of Guise and further alienated any sensibilities towards compromise with the Protestants. ${ }^{65}$ Finally, Catholic Mary I of England (1553-1558) died in November and Protestant Elizabeth I (1558-1603) succeeded, which again prompted fears of an English attempt to remove forcibly the confessional border. ${ }^{66}$ Furthermore, Henry II had lobbied the pope to take action in support of Mary, Queen of Scots' claim to the English throne instead of Elizabeth's, and Guise's leverage with Henry II would be weakened if she did not employ "a more overtly Catholic religious policy" in Scotland. ${ }^{67}$ Therefore, by the beginning of 1559 , Mary of Guise was in no mood or position to continue her conciliatory approach towards the Protestant cause.

With tensions on the rise, the Reformation Crisis was sparked on 11 May 1559 when a mob in Perth, inspired by a fiery sermon by John Knox, began a run of iconoclastic riots that quickly attracted supporters from other regions, including 2,500 from Ayrshire. In retaliation, Guise stationed troops in the burgh and, as Ryrie has observed, the "revolt quickly escalated into civil war" in the course of a few days. ${ }^{68}$

\footnotetext{
${ }^{64}$ Dawson, Scotland Re-formed, 197; Ryrie, 151.

${ }^{65}$ Ryrie, 151.

${ }^{66}$ Dawson, Scotland Re-formed, 201.

${ }^{67}$ Dawson, Scotland Re-formed, 201; Ryrie, 152.

${ }^{68}$ Ryrie, 161.
} 
Shortly thereafter, the earl of Argyll and Lord James Stewart, the half brother of Queen Mary, declared their support for the rebels and the Congregation, which added incredible political and military might to the Protestant cause. ${ }^{69}$ In January 1560, the Congregation successfully negotiated for English military assistance and, by spring, had secured the loyalties of the majority of the ruling elite, primarily due to their opposition to the French presence. ${ }^{70}$ By the time of Mary of Guise's death in June 1560 , the Congregation had gained the advantage and was recognized as the victor by both sides in July. The Treaty of Edinburgh was signed on 6 July, which mandated the departure of all foreign troops. A month later, when members of the Congregation controlling the government, a parliament was held, which declared Reformed Protestantism as the new religion of the kingdom, voided the papacy's jurisdiction over Scotland, and outlawed Catholic services. ${ }^{71}$ In December 1560, the first meeting of the General Assembly of the new Kirk was held and clerics and laymen ironed out the basics of Kirk administration and religious practices. ${ }^{72}$ Arrangements for ecclesiastical discipline, regarded by Scottish Reformed Protestants as one of the hallmarks of the "True Kirk," were delineated by John Knox and other divines in the Book of Discipline. Although the Parliament of January 1561 did not ratify the document because of squabbles over Kirk revenues, a good portion of the other

\footnotetext{
${ }^{69}$ Ryrie, 162.

${ }^{70}$ Ryrie, 163, 171.

${ }^{71}$ Dawson, Scotland Re-formed, 212.

${ }^{72}$ Dawson, Scotland Re-formed, 221.
} 
provisions were implemented nonetheless with the backing of many secular leaders. ${ }^{73}$ Thus, in the space of a few years, a once obstinately-Catholic kingdom had become proudly Protestant in theory, although the sincere and personal adoption of Protestantism for many individuals was long in coming. ${ }^{74}$

Remarkably, the newly-Protestant Scotland continued to be ruled by a Catholic monarch. In return for promising not to interfere in national religious matters, Queen Mary was allowed to practice her faith privately. ${ }^{75}$ In a lesson learned from her mother, Mary sought an amicable relationship with leading Scottish Protestants, since they were her best resource in her efforts to gain formal recognition by Elizabeth I as heir to the English throne. This desire of Mary to become queen of England was heightened after the death of her husband, King Francis II of France, in December 1560 and her subsequent return to Scotland in August $1561 .{ }^{76}$ Therefore, the first few years of her personal reign were relatively calm on the religious front. ${ }^{77}$

Despite Queen Mary's signals of her commitment to national Protestantism, Queen Elizabeth continued in her refusal to name officially Mary as her heir. Believing that a meeting face-to-face would win over Elizabeth, much like Henry VIII's failed attempts to meet with James V in person to woo him away from Catholicism, a rendezvous in York in the summer of 1562 was arranged by Mary, only

\footnotetext{
${ }^{73}$ Graham, 40-41.

${ }^{74}$ McCallum, 1.

${ }^{75}$ Lynch, Scotland, 210.

${ }^{76}$ Dawson, Scotland Re-formed, 215, 245.

77 Dawson, Scotland Re-formed, 252.
} 
to be called off by Elizabeth in March after Mary's uncle, the Duke of Guise, led a massacre of Huguenots in Vassy. ${ }^{78}$ Ultimately, the best strategy for obtaining recognition, if formal recognition was ever seriously to be considered by Elizabeth, was marriage. From the Scottish point of view, the leading candidate was Mary's English-born cousin and second-in-line to the English throne Henry Stewart, Lord Darnley and Master of Lennox. Darnley's father, Matthew Stewart, fourth Earl of Lennox, had fled to England after supporting the English cause during the Rough Wooing of the 1540s and, as the marriage discussions progressed, Lennox not only returned to Scotland in the fall of 1564 , but was allowed by parliament to reclaim his lands from the Hamiltons, thus adding friction to an already divisive court. ${ }^{79}$ The Darnley match was supported by the leading Protestants on the Privy Council because, as Dawson has observed, "they mistakenly assumed that" he and his father "would support their own Anglophile policy" given their English connections and interests. As Lennox was quickly elevated to the role of chief advisor by Mary, however, it became clear that he would only be catering to the queen's personal prejudices. ${ }^{80}$

Thus, as Mary's attention was increasingly monopolized by Lennox and the matter of securing succession, coupled with the arrival of Darnley (and his "dazzling good looks" and charm) in February 1565, she made the bold decision in March to

\footnotetext{
${ }^{78}$ Dawson, Scotland Re-formed, 247; Colin Jones, The Cambridge Illustrated History of France (Cambridge: Cambridge University, 1994), 140.

${ }^{79}$ Gordon Donaldson, Scotland: James V to James VII (Edinburgh: Oliver \& Boyd, 1965), 116-117; Lynch, Scotland, 214.

${ }^{80}$ Dawson, Scotland Re-formed, 252-253.
} 
marry Darnley, without the formal support of Elizabeth or any international rulers. ${ }^{81}$ Although Mary, and to a lesser extent Darnley, sought to quell concerns that the marriage signaled a move away from the English alliance, a group of rebels, led by James Stewart, now the earl Moray, Arran, now the duke of Chatelherault, and Archibald Campbell, fifth earl of Argyll, took up arms in protest in August 1565, just a month after the wedding. Hampered by conflicting interests and a lack of English backing, the rebels were quickly dispersed in the "Chaseabout Raid" and Moray excused himself to England. ${ }^{82}$ On the surface, therefore, it appeared at the end of 1565 that Mary, who was now pregnant, had subdued political and religious tensions, even reconciling with Chatelherault and the Hamiltons. In a way, the Chaseabout Raid had demonstrated Mary's resolve to maintain the independence and sovereignty of Scotland and commitment to neutralizing radical elements. ${ }^{83}$

Early in the following year, however, Mary's notions of religious harmony were compromised by her decidedly pro-Catholic measures, including encouraging Catholic nobles to celebrate Mass and Darnley's award of the French Order of St. Michael. These actions, coupled with a resurgence in the anti-Protestant efforts of France and Spain, led Protestants as well as those who feared foreign invasion to be deeply troubled by the current climate. ${ }^{84}$ At court, tensions between Mary and

\footnotetext{
${ }^{81}$ Dawson, Scotland Re-formed, 254; Roger Mason, "Renaissance and Reformation," in Scotland: A History, ed. Jenny Wormald (Oxford: Oxford University, 2005), 132.

${ }^{82}$ Dawson, Scotland Re-formed, 255; Mason, 133.

${ }^{83}$ Dawson, Scotland Re-formed, 255.

${ }^{84}$ Dawson, Scotland Re-formed, 255; Mason, 133.
} 
Darnley, already high as the result of the latter's exceptionally scandalous and petulant behavior (Gordon Donaldson has described him as "morally and intellectual worthless"), reached a boiling point when Mary revoked her promise to grant her husband the crown matrimonial, driving him into the arms of the agitated Protestant faction. ${ }^{85}$

Having dumped Lennox as her main advisor and increasingly ignoring the Privy Council, Mary turned to her personal attendants, including her Italian Catholic secretary, David Riccio, for counsel. Despite Mary's pregnancy, Darnley's indignation overruled any of his remaining common sense and, with a handful of Protestant collaborators, he proceeded to viciously stab and murder Riccio just feet away from the queen in March 1566. Fearing further violence and disorder, Mary took swift and direct action, managing not only to persuade Darnley to drop his alliance against her, but also to pacify once again the Protestants rebels. ${ }^{86}$ In a show of contrition, Mary pardoned Moray and Argyll and allowed them to return to court shortly after the murder and additional pardons were granted to other conspirators in the summer and in December. ${ }^{87}$ More broadly, having realized the implications of her "'Catholic interlude,"' Mary quickly abandoned her attempts at rehabilitating the Catholic cause and sought to restore friendly relations with Scottish Protestants and England. Thus, by the time of James VI's (1567-1625) birth in June 1566, which helped strengthen her

\footnotetext{
85 Dawson, Scotland Re-formed, 256; Donaldson, 120.

${ }^{86}$ Dawson, Scotland Re-formed, 256-257.

${ }^{87}$ Lynch, Scotland, 215.
} 
hold on royal power and her claim to the English throne, Mary's reign had returned to a relatively even keel. ${ }^{88}$

As was the pattern of Mary's troubles, however, the new year brought fresh upheavals. The birth of a son and heir had not repaired the royal marriage and the forces against the king were growing. Although it is unknown who murdered Darnley in February 1567, it is likely that Moray, Argyll, James Hepburn, the earl of Bothwell, and George Gordon, the fifth earl of Huntly, who had been restored in 1565, were in on a plot to oust the king. Whatever the actual circumstances, the removal of Darnley was a welcomed occasion for the royal court, if not explicitly expressed. Indeed, it was Mary's noticeable lack of grief or concern—she even had the "bad form" to attend a wedding the next day — that would work against her many years later as a prisoner of Elizabeth. ${ }^{89}$

At the urging of Elizabeth, who had halted succession negotiations, Mary relented and called a trial in April for the suspected murderer Bothwell, who was subsequently acquitted without much fuss. ${ }^{90}$ Bothwell, a member of Mary's Privy Council since her arrival in Scotland, had at some point obtained her affections and trust and persuaded the her, essentially by the means of abduction to his castle in Dunbar, to marry him on 15 May $1567 .{ }^{91}$ As with her previous marriage, Mary rushed in without taking proper assessment of the implications and without much outside

\footnotetext{
${ }^{88}$ Dawson, Scotland Re-formed, 255, 257-258.

${ }^{89}$ Dawson, Scotland Re-formed, 259-260.

${ }^{90}$ Dawson, Scotland Re-formed, 260; Mason, 134.

${ }^{91}$ Dawson, Scotland Re-formed, 245, 261.
} 
counsel. Her third marriage, however, proved almost immediately to be a step too far. On 15 June, the couple and their supporting forces met the Confederate Lords in armed confrontation at Carberry Hill, just outside of Edinburgh. With both sides wishing to avoid the possibility of outright war, Mary agreed to surrender and Bothwell was allowed to flee the country. Mary was removed to Loch Leven castle and, a little more than a month later, was made to abdicate, "deposition by any other name," Dawson contends. ${ }^{92}$

The year-old James was crowned at Stirling on 29 July and Mary agreed to allow Moray to become regent a few weeks later. ${ }^{93}$ The Parliament of December 1567 was dominated by two main concerns: the Kirk and the former queen. Further endearing himself to Kirk leaders, Moray re-enacted the 1560 Acts of Reformation as they had not been ratified by Mary, and the coronation oath for future monarchs was legally altered to conform to Protestant criteria. ${ }^{94}$ In an attempt to justify the actions of Mary's opponents at Carberry Hill, legislation was passed that convicted Bothwell of Darnley's murder and essentially named Mary as his accessory. Thus, the parliament found that Mary "justly deserves whatsoever has been done to her in any time past," and those that took action against her "were and shall be innocent, free and acquitted." It should be emphasized, however, that there was no move to deny Mary's son or his heirs the throne. ${ }^{95}$ Therefore, from this legislation, it is evident that Moray

\footnotetext{
92 Dawson, Scotland Re-formed, 261-262; 266.

93 Dawson, Scotland Re-formed, 267-268.

94 Dawson, Scotland Re-formed, 267-268

${ }^{95}$ A1567/12/18, Records of the Parliaments of Scotland.
} 
and his adherents, who included, rather bizarrely, Lennox, were politically vulnerable and keen to provide a legal basis for their assumption of government. ${ }^{96}$

For her part, Mary was unwilling to release fully her rights and claims to govern and had the backing of many powerful magnates. Tellingly, the division of support between Mary and Moray was not necessarily determined by religious sympathies. Indeed, Mary's allies included the ardently-Catholic Huntly and the equally ardently-Protestant Argyll. ${ }^{97}$ Given the exceptional measure of the abdication, therefore, many political leaders set aside religious differences in an attempt to restore the pre-1567 state of government as much as possible. It is not surprising, therefore, that a force of six thousand gathered in military opposition to the king's party after Mary's escape from Lochleven Castle on 2 May $1568 .{ }^{98}$ A series of strategic and tactical blunders, however, resulted in the defeat of the queen's men at the battle of Langside on 13 May. ${ }^{99}$ Spooked, Mary made another hasty decision and fled to England in the hope that Elizabeth would assist a fellow monarch in distress. For a variety of reasons, Elizabeth retained Mary in England and, after years of negotiations, plots, diplomatic maneuvering, and two trials, Mary was executed for treason against England in February 1587. ${ }^{100}$

\footnotetext{
96 Dawson, Scotland Re-formed, 268; Mason, 135.

97 Mason, 134-135.

${ }^{98}$ Dawson, Scotland Re-formed, 269.

99 Mason, 135.

${ }^{100}$ Dawson, Scotland Re-formed, 270; Lynch, Scotland, 222.
} 
Meanwhile, James VI's minority was marked by upheaval. Moray was a man with many enemies and the list grew during his tenure as regent, especially as he was monetarily rewarded for his cooperation with Elizabeth during Mary's first trial in December 1568. ${ }^{101}$ After a tumultuous couple of years as regent, Moray was assassinated in January 1570, leaving a power vacuum and leading to another round of civil wars. ${ }^{102}$ Although a peace was reached in early 1573 , serious tussles over governance endured, even after James assumed personal rule in 1578, and it was not until the mid-1580s that stability returned. ${ }^{103}$

Through the events of the 1540s-1560s, the Gordon family, the magnates of the northeast, had played a prominent and influential role. In the $1550 \mathrm{~s}$, their pro-French/ pro-Guise alliance was necessitated not only by their staunch religious conservatism, but by their heavy reliance on royal support in order to maintain regional authority as well. ${ }^{104}$ In return, the Gordons had been rewarded with land and positions in national governance. Indeed, George Gordon, the fourth earl of Huntly, was made chancellor by Arran in 1546 following Cardinal Beaton's assassination. ${ }^{105}$ Magnatial power had limits, however. After a series of executions ordered by Huntly of regional Gordon rivals, Mary of Guise stripped him of the Great Seal in 1554 and transferred it and most of his authority to one of her French advisors in the position of Vice-Chancellor.

\footnotetext{
${ }^{101}$ Dawson, Scotland Re-formed, 268, 270.

102 Dawson, Scotland Re-formed, 271-272.

${ }^{103}$ Dawson, Scotland Re-formed, 280, 302; Lynch, Scotland, 233.

104 White, "Religion, Politics and Society in Aberdeen," 191.

105 Dawson, Scotland Re-formed, 167.
} 
Huntly's loyalty to the regent was compromised by this episode and would not be restored. ${ }^{106}$

Although he would eventually put his name to the Lords of the Congregation, Huntly's position was effectively neutral through most of the Reformation Crisis. Not only were he and his family firmly against Protestantism for a variety of reasons, but the northeast region as a whole was not open to other religious options. Consequently, his ability to wield authority over Catholics rested on his commitment to Catholicism. It was only in April 1560 that the political reality forced Huntly's hand into supporting the Congregation, but he made no attempt to support Protestantism and, predicting that the new settlement would soon be overturned, he and his uncle made their excuses from the Reformation Parliament. ${ }^{107}$ Fearful that the northern earl would sabotage Scotland's alliance with England, James Stewart, Argyll, and John Stewart, the fourth earl of Atholl, met in September 1560 to discuss, as reported to Elizabeth I's advisor from the English ambassador to Scotland, how to "bridle" Huntly, "as his nature and behaviour gives occasion of mistrust."108

Upon her return to Scotland in August 1561, Mary agreed with her halfbrother's assessment of Huntly and, although the earl remained chancellor, they began taking steps behind the scenes to reduce Gordon power and tighten monarchial

\footnotetext{
106 Dawson, Scotland Re-formed, 190-191; Ryrie, 146.

107 White, "Religion, Politics and Society in Aberdeen," 196.

${ }_{108}$ White, "Religion, Politics and Society in Aberdeen," 196; Joseph Stevenson, ed., Calendar of State Papers, Foreign Series, of the Reign of Elizabeth, 1560-1561 (London: Longmans, Green, Reader, and Dyer, 1865), 283.
} 
sovereignty in the northeast. ${ }^{109}$ For his part, Huntly misjudged the queen's intentions regarding a Catholic restoration and did himself no favors by making his views known. Indeed, Huntly and Lord James openly quarreled in October 1561 over an alleged remark by the former that he would "set up the Mass in three shires" given the word by Mary. ${ }^{110}$ As this incident shows, Huntly's position was becoming increasingly untenable and Mary and Lord James devised a plan to remove indirectly a significant chunk of Huntly's power base. Since the fifteenth century, the Gordon family had held the earldom of Moray. In early 1562, however, the queen secretly transferred the earldom to Lord James. ${ }^{111}$ Mary arranged a tour of the northeast in the fall of 1562 and shortly before she was to visit Huntly, she publicly announced the transfer and Huntly responded by refusing to allow her entry into his castle at Inverness, although he was not present. This action implied rebellion to Mary and Lord James met Huntly in battle a few weeks later, where Huntly died of a heart attack; his eldest son, John, was later convicted of treason and executed and the earldom's estates were declared forfeit in May 1563. Thus, by the end of 1562, Mary had, in the words of Dawson, "plucked down the north-east's leading magnate" and sent a clear signal of her sovereignty. ${ }^{112}$ Although Huntly's downfall did not directly

109 Dawson, Scotland Re-formed, 245; White, "Religion, Politics and Society in Aberdeen," 200-201.

110 Joseph Stevenson, ed., Calendar of State Papers, Foreign Series, of the Reign of Elizabeth, 1561-1562 (London: Longmans, Green, Reader, and Dyer, 1866), 353-354; White, "Religion, Politics and Society in Aberdeen," 200-201.

111 Dawson, Scotland Re-formed, 246-247; White, "Religion, Politics and Society in Aberdeen," 202.

112 Dawson, Scotland Re-formed, 248-249. 
affect the affairs of Aberdeen, it did contribute to the burgh's implementation of reform, as will be discussed in the following chapter.

Fortunately for the Gordons, Lord James' fall from favor after the Chaseabout Raid prompted a restoration of the earldom to the late earl's second eldest son, George Gordon. Although not Catholic, the new earl was not decidedly Protestant either. Furthermore, Huntly retained a fierce resentment of Moray for orchestrating his father's ruin. Thus, his loyalty to the queen was assured and unlikely to be eroded by changes in the religious and political landscapes. It was not long before that loyalty was tested as Huntly not only aligned himself with the queen from the start of the Civil Wars, but was active and effective in her cause. ${ }^{113}$ Huntly had firm control over the northeast even after Mary's abdication and it was not until May of 1569 that Moray gained the upper hand, leaving the earl no choice but to "receive the King as his Sovereign, and obey his authority."114 With Huntly's capitulation, the nation was once again at peace, if only for a few years. ${ }^{115}$

By virtue of its location, Aberdeen was largely able to escape the worst of the various tumults of the sixteenth century that affected the south. In many cases, however, it was impacted directly by the larger political and religious developments. Throughout the century, Aberdeen's oligarchy not only sought to maintain its hold on

\footnotetext{
113 White, "Religion, Politics and Society in Aberdeen," 231.

114 White, "Religion, Politics and Society in Aberdeen," 240; Joseph Stevenson, ed., Calendar of State Papers, Foreign Series, of the Reign of Elizabeth, 1569-1571 (London: Longmans, Green, Reader, and Dyer, 1874), 263.

115 White, "Religion, Politics and Society in Aberdeen," 241.
} 
the burgh, but strove to retain the burgh's relative independence from regional and national powers as well. ${ }^{116}$ This objective was particularly put to the test during the 1560 s as the religiously-conservative burgh confronted the national agenda of reform.

It is against this backdrop that the following chapters will consider Aberdeen's implementation and interpretation of reform from 1560-1568.

116 White, "Religion, Politics and Society in Aberdeen," 12; White, "The Menzies Era," 224. 


\section{Chapter Two: Implementation of Reform}

As discussed in the previous chapter, Aberdeen's ill-fated involvement with James Hamilton, the earl of Arran's "'Godly fit"' of 1543 set the scene for its approach to the Reformation Crisis of 1559-1560. Inherently conservative to begin with, the lasting memory of the consequences of the burgh's association with Protestantism, albeit indirect, furthered the case to remain neutral through most of the Crisis. Indeed, the Menzies family, who were routed from power as a result of their early connection with Arran, had managed to regain their standing by 1559 and, therefore, were even less likely to take political risks. ${ }^{117}$ With the events of the 1540 s in mind, this chapter will trace and examine Aberdeen's experience with the Reformation Crisis and its subsequent implementation of reform through 1568.

Although May 1559 marked the beginning of the iconoclastic riots, it took more than a month for the burgh council of Aberdeen to react formally to the news and prepare the town for anticipated violence to the friaries and church buildings. Despite the clearly religious nature of such attacks in Perth and other southern localities, the Aberdeen council made no mention of the Protestant motivations; rather, they showed deep concern that the mob had taken direct action "without any order or consent of the authority," a theme that the council often would invoke in the coming months and years. Moreover, the council, at least as conveyed in the record, appears to have been

\footnotetext{
117 White, "Religion, Politics and Society in Aberdeen," 151.
} 
unconcerned for the welfare of the clergy, friars, or parishioners who might be in harm's way and does not refer to mounting any sort of defense for the Catholic Church and Catholicism. Instead, attention and effort was solely directed to the storing and protecting of the "chalices, silver work, copes, and ornaments" (known collectively as the kirk work) and the collecting of any outstanding rents owed to the chaplains of St. Nicholas. ${ }^{118}$ Given the absence of any expression of religious sentiment in this first record made during the Reformation Crisis, the council was clearly interested in remaining neutral and taking a practical approach to the religious turbulence that was upon the nation.

Indeed, through the summer and fall of 1559, there are no further entries in the council record regarding the unprecedented and monumental events that other parts of the realm were experiencing. ${ }^{119}$ Council business proceeded as it had done in the decades and centuries prior. The entries concerning St. Nicholas and its chaplains are rather banal: the appointing of a new chaplain to St. Michael's altar, continuing efforts of collecting back rents, and provision for the maintenance and repair of the church. ${ }^{120}$ There is no evidence in the council register for this time that would point to any serious concerns of threats, either external or internal, to the city and its Catholicism. ${ }^{121}$

\footnotetext{
118 Stuart, John, ed., Extracts from the Council Register of the Burgh of Aberdeen, 1398-1570 (Aberdeen: Spalding Club, 1844), 323-324.

119 White, "Religion, Politics and Society in Aberdeen," 153.

120 Extracts from the Council Register, 324-325.

121 White, "Religion, Politics and Society in Aberdeen," 153.
} 
However, by the late fall and early winter of 1559 , the advantage had tilted in favor of the Congregation and, as English troops began to mobilize in aid of Scotland and additional French reinforcements failed to materialize, the threat to Aberdeen's neutrality and safety increased. ${ }^{122}$ As such, the council made its political and religious allegiances known on 29 December 1559. Upon hearing that a mob, or "congregation" from Mearns and Angus was on its way to Aberdeen and was planning to "cast down the kirks and religious places," Thomas Menzies voiced his opposition to the mob's religious mission and called for his fellow council members to do likewise. In the entry for 16 June 1559, Menzies again cites the absence of authority for the congregation's actions and, in this instance, accuses the participators of "manifest treason." For the first time, the council refers to the religious intentions of the congregation, namely those "under color and pretense of godly reformation." These carefully-chosen words implicitly reveal the council's, and, in turn, the burgh's, adherence to and defense of Catholicism. Still, the primary concern of the council was to preserve authority and remove the burgh from any association with the riots: "this town ought incur no indignation of authority, nor be held culpable and participant of the said crime." As the entry ends with the naming of nine other present council members who "protested each for themselves" and echoed Menzies' statement, council solidarity appears to have been alive and well at the end of $1559 .{ }^{123}$

\footnotetext{
122 Dawson, Scotland Re-formed, 209; Ryrie, 163.

${ }^{123}$ Extracts from the Council Register, 326.
} 
On 4 January 1560, however, this unity was broken, at least temporarily. The ongoing ransacking and pillaging of the Dominican and Carmelite friaries and other local religious buildings prompted David Mar, a Protestant-leaning member of the burgh council and dean of the gild, to convene an emergency meeting of the council. Conveniently absent from the meeting were several leading members of the council, including Thomas Menzies, who would later claim that he was out of town on business. ${ }^{124}$ Acting on the opportunity of the moment, Mar attempted to implement a version of Protestant reform, which succeeded for the following seven days. ${ }^{125}$ Offered more as a practical measure than as a consciously religious act, Mar proposed commandeering the buildings and various incomes of the friaries for "the common weal and utility" of the town. Furthermore, he argued, taking up the cause of reform "would assist for the defense of the liberty of the realm, [and the] expelling of strangers," presumably meaning Guise's French troops and government officials. Significantly, Mar also contended, seemingly almost as an incidental afterthought, that this redirection would benefit "God's glory, and his true word and preachers" and would aid in the "suppressing of idolatry."126 This assertion, although subdued as compared to the fiery speech of ardent Protestants, was bold and potent, especially when placed in the context of Aberdeen's conservatism and considered as a indirect

\footnotetext{
${ }^{124}$ White, "Religion, Politics and Society in Aberdeen," 159; White, "Impact of the Reformation on a Burgh Community," 91; Extracts from the Council Register, 318.

125 White, "Impact of the Reformation on a Burgh Community," 91.

${ }^{126}$ Extracts from the Council Register, 315.
} 
challenge to Menzies' words of unflinching Catholic support spoken not even a week prior.

Ultimately, however, the argument put forth by Mar on 4 January focused on defending the nation's liberty, using similar language, as Allan White has noted, to that used by the "various bonds of the Congregation." 127 Deftly combining national defense with a hint of religious reform, Mar asked the council members present "openly to declare their minds" and decide the next steps to be taken by the council. All except one, Gilbert Collison, agreed with Mar's proposal and ordered a proclamation to be read publicly at the market cross and announce that any interference with the council's actions by the burgh's residents would not be tolerated. ${ }^{128}$ In the course of one day, therefore, Aberdeen's authorities placed the burgh on the path to Protestantism, a course not considered since 1543.

Just four days later, however, the Catholic faction of the council began to reassert its authority. David Mar again led the meeting and reiterated his agenda. However, Gilbert Menzies, the younger, speaking on behalf of Thomas Menzies and other council members, took umbrage at the council's decisions made on 4 January, essentially accusing them of treason as such actions were "contrary to the mind of the authority," that is to say, to the rule of the monarch and to Aberdeen's burgh authorities. Furthermore, Mar's proposal was not valid because of the absence from

\footnotetext{
127 Extracts from the Council Register, 315; White, "Impact of the Reformation on a Burgh Community," 91.

${ }^{128}$ Extracts from the Council Register, 315.
} 
that earlier meeting of a good portion of the council who were thus unable to voice their opposition. Therefore, the controlling portion of the council once again rejected any participation in reform and reaffirmed that the burgh would not be held liable for any "danger and damage" incurred by the rioters. ${ }^{129}$ In an attempt to salvage his authority and, as White has noted, "in a last desperate effort to lay hands on some of the property of the old Church," Mar issued a directive for Gilbert Collison and three other council members to take temporary possession of the "chalices, silver work, and ornaments" from St. Nicholas and to be closely monitored until a longer-term plan could be agreed upon. ${ }^{130}$ Clearly, the council's Protestant sympathizers had begun to lose their already tenuous grip on the possibility of reform. However, Mar's shortlived triumph foreshadowed a turning of the tide that would occur in the spring of 1560.

Nevertheless, the return of Thomas Menzies to the council meeting on 12 January 1560 put the issue of reform decisively to rest for the present. In his appeal to the council, he employed two prongs of attack, both of which revolved around the question of legality. Firstly, because a majority of those involved in the "destruction and dissipation" of the religious houses were non-residents, the council's decision to "continue and complete the destruction begun by others" was against "the will of the

${ }^{129}$ Extracts from the Council Register, 316.

${ }^{130}$ Extracts from the Council Register, 317; White, "Religion, Politics and Society in Aberdeen," 160. 
authority" and amounted to the "aiding and abetting" of crimes "to the great...detriment of this burgh, and the poor innocent burgesses thereof."131

Secondly and more significantly, on 29 July 1559, Regent Mary had agreed to a six-month truce with the Lords of the Congregation whereby Protestant preachers and the properties of the Congregation's members would not be troubled by the authorities in return for an end of the seizing of Church property by Protestants. As the agreement ended on 10 January 1560, Menzies asserted that the authorities' continued possession of Church property and funding of Protestant preachers was in direct violation of the terms of the truce. ${ }^{132}$ As such, Menzies "and his adherents" called for an immediate cessation of the council's participation in the "said crimes" and prohibition against the payment of preachers by David Mar. Those adherents included fifteen other council members who were absent from the previous meetings, due to business demands, and expressed their indignation at not being informed of the council's proposals. ${ }^{133}$ Because of these well-timed absences, Menzies and other conservatives waited out the expiration of the truce and subsequently challenged Mar's decisions on legal grounds, rather than confront the issue of religion directly and explicitly. As a result, Mar and his supporters were effectively shut down by the conservative faction without any shots being fired in defense of the old religion or any

\footnotetext{
${ }^{131}$ Extracts from the Council Register, 318.

132 Extracts from the Records of the Burgh of Edinburgh, 47; White, "Religion, Politics and Society in Aberdeen," 161; Donaldson, 94.

133 Extracts from the Council Register, 319.
} 
strikes by the new. Stability and control were the overriding goals of Provost Menzies and his showing at this meeting reaffirmed his hold on Aberdeen's politics.

For the next few weeks, the council record gives the impression of relatively calm seas in the burgh. ${ }^{134}$ On 13 January 1560 , the original keepers of the kirk work transferred their goods to a new set of temporary holders. ${ }^{135}$ Included in the entry is the inventory of those extensive and valuable holdings from St. Nicholas, which demonstrates the amount of wealth that the burgesses of Aberdeen had invested in their parish church for centuries. Among the items were ten silver chalices totaling almost two hundred ounces of silver and six copes of rich velvet and embroidered with gold. ${ }^{136}$ This list is another example of what the burgh stood to lose as a community if reform was implemented. Other ordinary business of the council is recorded as well, such as the ongoing collection of back rents and fees owed to the chaplains. ${ }^{137}$

Among these routine entries, however, is a provision on 23 January 1560 for the prepping of artillery by the "master of the blockhouse" Gilbert Menzies, the younger, for "when," not if, "the town happens to have an ado." Additionally, the council announced that the town would take possession of the Observant Franciscan friary as "the said friars have resigned all their title and interest of the said place in favor of the town." As such, the burgh was to assume the responsibility for protection

\footnotetext{
134 White, "Religion, Politics and Society in Aberdeen," 163.

135 Extracts from the Council Register, 319.

136 Extracts from the Council Register, 320.

${ }^{137}$ Extracts from the Council Register, 321-322.
} 
and four men were stationed at the friary to keep guard. ${ }^{138}$ As with events earlier in the month, Aberdeen was no longer isolated from the national turmoil and proactive measures by the authorities were necessitated.

By the spring of 1560, it was clear to the burgh's ruling elite that Aberdeen had to start taking steps towards aligning with the Congregation as the fourth earl of Huntly and other regional nobles began to ditch their loyalties to the regent. Although Huntly formally joined the Congregation in April 1560, Aberdeen had taken the initiative a month earlier, once again asserting its independence from outside parties. ${ }^{139}$ After decades of resisting Protestantism and reform, the burgh of Aberdeen officially aligned itself with the Congregation and, by default, its Protestant cause on 8 March 1560. The respective record entry reads as though spoken through clenched teeth. In a matter of a few paragraphs, the council hitched the burgh's wagon to the fortunes of a revolution. Tellingly and unlike other burghs' proclamations, this announcement makes no reference to religion. Instead, political expediency, "defense of the liberty," and the "common weal of this burgh," were the only motivations cited for the council's decision. Given the numerous appeals to rule of law in previous entries opposing reform, the council emphatically asserted that it was not acting against the "queen's grace and her authority," but needed to react in the interests of the burgh's welfare. Only Gilbert Collison, the objector of 4 January, voiced his opposition to the alliance, contending that it indeed was "contrary to the authority of

${ }^{138}$ Extracts from the Council Register, 321.

139 White, "Impact of the Reformation on a Burgh Community," 92-93. 
Scotland." Nevertheless, a formal alliance was established and the council consented to raise a burgh tax of $£ 400$ for the "furnishing of forty men of war," out of a burgh population of around 5,500, who would join the Congregation. ${ }^{140}$ Although Aberdeen directly contributed relatively little to the Congregation and did not share its professed religion, the alignment was nevertheless remarkable as the Congregation was now able to count another major burgh among its membership. For Aberdeen, the alliance removed the threat of forceable occupation by the Congregation's forces, allowed its authorities to retain control over the burgh's affairs, and freed them to redirect their energies into implementing reform on their own terms.

As mentioned previously, the realm of Scotland formally adopted Reformed Protestantism during the Reformation Parliament of August 1560. On 30 September 1560, Thomas Menzies took the oath of office for another yearly term as provost of Aberdeen. Although the oath reflects the new national religion in theory, its vague wording and generalities indicate the reticence of a Catholic burgh council in a Protestant nation. Although further research is necessary, the available records do not contain a similar oath and the entry does not reference a source, so it is presumed that this oath was a new addition necessitated by the Confession of Faith, which is similar in several key respects. ${ }^{141}$ Like any oath of civil office, the provost promises to "duly exercise the office...without feud or favor" and maintain the "liberty and privilege of

\footnotetext{
140 Extracts from the Council Register, 322; Dennison, Ditchburn, and Lynch, preface to Aberdeen Before 1800, xxvi.

${ }^{141}$ A1560/8/3, The Records of the Parliaments of Scotland.
} 
this burgh, for the common weal and profit thereof." The remaining portion of the oath, however, explicitly concerns the religious duties of the provost. Firstly, the oath affirms God as the creator, who "made men...to be just and true in all promises according to his godly will." Secondly, the oath reminds the taker and the witnesses that he is swearing in God's "presence and his holy angels" to add validity and weight to the oath.

Thus far, the religious content is rather neutral and could easily be taken from pre-Reformation speech. However, the main message of the oath, which comprises nearly half, tacitly invokes the cause of the Reformation:

I do here promise...[to] maintain and set the faith and religion of Jesus Christ at my utter power, and shall be enemy to all them that resists and stands against the same. Also I shall assist, concur, fortify, and set all things ordained and concluded to be done by the noble council of this good town in all things concerning the advancement of God's glory and the liberty and freedom of this burgh and community thereof, in equality and justice....at the will and pleasure of God; which I avow and promise to observe in presence of God and this congregation. ${ }^{142}$

Given the known and unapologetic Catholicism of the provost and most of the council at this time, it comes as no surprise that there is no explicit reference to the "true" faith of Protestantism, unlike in David Mar's address on 4 January 1559, but it is clear that the oath is informed by, albeit perhaps grudgingly, the newly-adopted national religion. In particular, the inclusion of the term "congregation," a favorite of Protestants, is a subtle, but marked a change from "community" as used in prior

\footnotetext{
142 Extracts from the Council Register, 328.
} 
entries. In this instance, Aberdeen is not identified as a secular community; rather, it is a congregation of God.

As the civic leader of that congregation, the provost asserted his religious duties. Indeed, the Confession of Faith charges civil authorities, from monarchs to city magistrates, with the "maintenance of the true religion and for the suppressing of idolatry and superstition." While Aberdeen's officials may not have warmly embraced this directive, the Confession's repeated appeal to and affirmation of authority fits in neatly with their preoccupation with preserving civil authority. ${ }^{143}$ Moreover, the Confession asserts that authorities are "ordained by God" and must be "loved, honoured, feared and held in most reverend estimation, because they are the lieutenants of God, in whose sessions God himself does sit and judge." These principles must have been especially pleasing to Aberdeen's ruling elite as not only did they reinforce the burgh's tightly controlled political structure, but elevated the importance of the authorities as they now had the backing of God as well. Any individual who disobeyed the magistrate, disobeyed God in turn. ${ }^{144}$ As Allan White has observed, the Reformation "allowed the council to extend the control it had enjoyed over the local Church before 1560, and to develop the sense of the burgh's religious self-sufficiency." 145

\footnotetext{
143 White, "Religion, Politics and Society in Aberdeen," 353.

${ }^{144}$ A1560/8/3, The Records of the Parliaments of Scotland. The fifth Commandment speaks to God's demand of obedience to authority and was employed by Aberdeen's kirk session in its founding legislation in 1562, which will be discussed in the following chapter.

145 White, "Religion, Politics and Society in Aberdeen," 353.
} 
In the remaining months of 1560 and early in 1561 , the council prudently issued decrees that furthered the establishment of reform. In early October 1560, Adam Heriot's annual salary was set at $£ 200$, a handsome sum that was on par with John Knox's and, as White believes, a reward for the minister's "lack of fervour." ${ }^{146}$ In other efforts to dampen any fervor among the residents, the council imposed strict penalties for assaulting clerics or looting the religious houses. ${ }^{147}$

On 6 December 1560, the feast day of St. Nicholas, the council proclaimed a moratorium for the day on selling goods at the market and violators faced a severe fine of $£ 10 .{ }^{148}$ It is difficult to ascertain the reason behind this suspension of business, but two viable possibilities may be conjectured. The most obvious possibility is the celebrating of the burgh's patron saint, especially as the day falls on a Friday, ruling out a connection with the Sabbath. ${ }^{149}$ If so, then the entry indicates that the council and the burgh's residents were blatantly unconcerned about proceeding with preReformation practices and beliefs, even if not officially expressed in a religious context. The second possibility is an official day of mourning for Francis II, husband of Queen Mary and King Consort of Scotland, who had died unexpectedly the previous day. Given the fact that he died in France, however, it seems unlikely that

\footnotetext{
146 Aberdeen Council, Baillie and Guild Registers, vol. 24, fo. 10; White, "Religion, Politics and Society in Aberdeen," 288.

147 Aberdeen Council, Baillie and Guild Registers, vol. 24, fo. 38, 47; White, "Religion, Politics and Society in Aberdeen," 163.

148 Extracts from the Council Register, 328.

149 Cheney, 80, 203; Dennison, introduction to Aberdeen Before 1800, 7.
} 
news would have reached Aberdeen that quickly. ${ }^{150}$ Although a definite conclusion cannot be reached without more extensive research, the entry is nonetheless significant as it gives a glimpse into the religious and/or political mindset of burgh authorities.

The following day, it is briefly noted that Gilbert Collison returned to the council various items from St. Nicholas that he had been holding for safekeeping, including "two great chandeliers of Saint Nicholas high altar, with the Sacrament chandelier," which indicates that the town had accepted the prohibition of such ostentatious and symbolically-charged ornaments from the pre-Reformation Church. Furthermore, it may signal that the council was preparing to sell church furnishings. ${ }^{151}$ The council also agreed in December to send Thomas Menzies and David Mar to attend a gathering of the nobility in Edinburgh the following month. ${ }^{152}$ The major item on the agenda was to approve the Book of Discipline, or at least the majority of its directives, so as to strengthen the Kirk's foundations in anticipation of Queen Mary's return. ${ }^{153}$ Notably absent among the signatures of the document's acceptance were those of Aberdeen's representatives.

On the surface, this absence indicates Aberdeen's unwillingness to abide the swelling tide of reform. ${ }^{154}$ However, as Allan White has shown, it was a calculated political move that was designed to stall Aberdeen's absolute commitment to either

\footnotetext{
150 Dawson, Scotland Re-formed, 215; Lynch, Scotland, 209.

${ }^{151}$ Extracts from the Council Register, 328-329.

152 Aberdeen Council, Baillie and Guild Registers, vol. 24, fo. 83; White, "Religion, Politics and Society in Aberdeen," 189.

153 Donaldson, 104.

${ }^{154}$ Presumably, Protestant Mar was obliged to follow Menzies' example and not sign.
} 
side. On one hand, their refusal to sign placated Huntly and allowed more time to gauge Queen Mary's intended course of action. On the other hand, their presence at the convention signaled at least some willingness to cooperate with leading Protestants. ${ }^{155}$ Furthermore, Menzies must have felt enough pressure from influential Protestants to impose a stricter "religious test" on St. Nicholas chaplains. In October 1560, the guild court, headed by Protestant David Mar, decreed that the chaplains of St. Nicholas, who were largely patronized by the various guilds, were to attend reformed services or forfeit their rents. ${ }^{156}$ At this time, there was no stipulation that they hold Protestant beliefs or participate in Protestant sacraments. ${ }^{157}$ Following the convention, however, an entry regarding the collection of rents employs modified language. The new requirement stated that the chaplain must have already been admitted to the "congregation," which implies that they were to be participating fully in reformed services. ${ }^{158}$ As White has tracked, a handful of chaplains chose not to abide by the new terms and subsequently retired or found creative ways of sidestepping the requirement while still collecting rents. Like other Catholic clergy, the chaplains were advantaged by their familial connections to council members. ${ }^{159}$

\footnotetext{
155 White, "Religion, Politics and Society in Aberdeen," 190.

${ }^{156}$ Aberdeen Council, Baillie and Guild Registers, vol. 24, fo. 13; White, "Religion, Politics and Society in Aberdeen," 188; Lynch and DesBrisay, "The Faith of the People," 292.

157 Aberdeen Council, Baillie and Guild Registers, vol. 24, fo. 13; White, "Religion, Politics and Society in Aberdeen," 188.

158 Aberdeen Council, Baillie and Guild Registers, vol. 24, fo. 195; White, "Religion, Politics and Society in Aberdeen," 173.

159 White, "Religion, Politics and Society in Aberdeen," 174-175.
} 
As old clergy were removed or repurposed, new kirk officials were brought in. Aside from Minister Heriot, it was necessitated that a reader be appointed, who was to read and recite "common prayers and the scriptures" to the congregation as stipulated by the Book of Discipline. ${ }^{160}$ John Leslie was given the position in early 1563 and assigned a yearly salary of ten pounds. As the Book of Discipline suggested forty merks or roughly twenty-seven pounds as salary, Leslie's salary was well below what other parish readers were receiving. ${ }^{161}$ By 1566, it appears that the council was behind in its payments to Leslie, leading him with some boldness to bring the matter before the council and request not only to be paid, but to have his total salary increased by $£ 10$. Although the request was granted, it is telling that the council was more than willing to provide for former Catholic clergy and was presumably diligent in their payments, but Leslie, a clerical newcomer and Protestant, was given the short shrift. ${ }^{162}$ The challenge of accommodating Catholic ex-clergy was not resolved for some time, especially as most rejected assimilating into the new Kirk. ${ }^{163}$ Indeed, White has determined that at least five former chaplains plus many more friars were resident in the burgh in 1575.164

Unlike the chaplaincies of St. Nicholas, the friaries did not receive a reprieve and on 18 April 1561, David Mar was given the go-ahead, despite protestations of

\footnotetext{
160 James K. Cameron, ed., The First Book Of Discipline (Edinburgh: The Saint Andrew Press, 1972), 106.

161 Extracts from the Council Register, 356; First Book of Discipline, 111.

162 Extracts from the Council Register, 362; White, "Religion, Politics and Society in Aberdeen," 232.

163 White, "Religion, Politics and Society in Aberdeen," 177.

164 White, "Religion, Politics and Society in Aberdeen," 283.
} 
Gilbert Menzies and Gilbert Collison, discussed previously, to "receive and uptake the rents...of the friars crofts, to be applied to the town's utility and profit." Although the town sought to preserve much of the old ways and institutions, the friaries stood no chance of survival as they had been a particular target of the Reformers. ${ }^{165}$ Aberdeen learned early on to choose its battles and the friaries were sacrificed in order to gain room to maneuver in other matters.

From the beginning of 1562, the implementation of reform gained speed. On 6 January 1562, the council sold the "silver work, brass work, copes, and ornaments" of St. Nicholas to "them that will offer most for the same." The money generated from the sale was to be "applied to the common weal and necessary ados of this good town," while specific support of new Kirk is not referenced. ${ }^{166}$ This disposal of such long-cherished items was a significant step towards complying with the demands of the new Kirk, especially since it took the council nearly seventeen months to determine to take this action. Remarkably, only Gilbert Menzies and Gilbert Collison objected to the sale, whereas the majority of the council had objected to David Mar's proposals in early January 1560 . If not embracing Protestantism, the council was at least understanding of the new era's political realities. Patrick Menzies is listed as the only buyer, paying $£ 540$ for the lot. Curiously, the metal items were auctioned not as

\footnotetext{
165 Ryrie, 123-126.

166 The entry for 8 May 1562 explains that the "whole money gotten" for the kirk work" was to be "applied upon the building and restoration of the pier and key head" along with "the artillery and munitions pertaining to the town." Thus, it is confirmed that no funding was directed towards supporting the new religion and ministry. See Extracts from the Council Register, 344.
} 
individual pieces, but by the ounce, which may indicate that the intent was to melt them down for resale rather than repurpose them. ${ }^{167}$

Six days after the sale of the kirk work, the council received the news that Queen Mary would be visiting "the north parts to survey the same" sometime in the next fourteen months. Not only would this visit demand an elaborate reception, of which an initial two thousand merks was raised in preparation, but, as her party would include the queen's half brother Lord James Stewart, a committed member of the Lords of the Congregation, the burgh would need to exhibit further reform than what it had already achieved or risk falling foul of the Protestant elite. ${ }^{168}$ The most significant piece of reform was the establishment of the kirk session in November 1562, spurred by the royal party's visit in the fall of 1562, the earl of Huntly's defeat in October, and Lord James' subsequent presence in the region, as discussed in the previous chapter. ${ }^{169}$ However, several smaller steps were required as well. Concerning the various lands and attached rents of the friaries and other theoretically-former Church property, in February 1562, the council nominated Thomas Menzies to "labor and entreat at the queen's hand and the lords of the secret council" in Edinburgh. The reason for the meeting concerned the properties of the various religious houses and presumably because the council was angling for the right to keep the majority of the lands and rents instead of transferring them to the new Church. ${ }^{170}$ Indeed, this issue was one of

\footnotetext{
${ }^{167}$ Extracts from the Council Register, 329.

${ }^{168}$ Extracts from the Council Register, 339; Dawson, Scotland Re-formed, 205.

169 White, "Religion, Politics and Society in Aberdeen," 169.

${ }^{170}$ Extracts from the Council Register, 330.
} 
the main bones of contention in the years and even decades after the Reformation, nationally and locally. In the short-term, a 33\% tax was placed on benefices of the pre-Reformation Church and the tax revenue income generated was further split evenly between the new Kirk and the Crown. Although each party had objections to this system, it was successful and helped stabilize government income. ${ }^{171}$

One of the main tenets of Reformed Protestantism was ecclesiastical discipline, which was to be administered by both the religious and secular authorities. The Book of Discipline, drawn up by Scottish Protestant divines in the spring of 1560 and adopted piecemeal by various national and local ruling bodies, specified the transgressions that fell under civil and Kirk jurisdiction and their appropriate penalties. ${ }^{172}$ Discipline was crucial to a functioning godly society because no "commonwealth can flourish or long endure without good laws...so neither can the church of God be brought to purity, neither yet be retained in the same" in the absence of discipline. ${ }^{173}$

The first recorded instance of this new form of discipline in the registers of Aberdeen's council, given that a kirk session had yet to be created, is in mid-March 1562. One Hector Dolloquhy was found guilty of assaulting Elspeth Irving and was sentenced to attend the following Sunday's church service at St. Nicholas kirk "and there, in presence of God and his holy congregation, ask the said Elspeth forgiveness,

\footnotetext{
${ }^{171}$ Lynch, Scotland, 211; Dawson, Scotland Re-formed, 251.

172 Graham, 40; The First Book Of Discipline, 85-86.

173 The First Book Of Discipline, 165.
} 
and to revoke the injurious words said by him as false and untrue." 174 Similarly, a woman convicted of assault in late November 1562 was fined and ordered to "ask God and the party offended forgiveness, with a contrite and penitent mind."175 As analyzed by Michael Graham in his study of post-Reformation discipline and Margo Todd in her work on repentance, these cases were fairly typical, both in the committed offense and the assigned punishment. ${ }^{176}$ However, in mid-June 1562, the council does not call for a public repentance in church by a woman accused of adultery. Instead, her husband is to once again "accept...his spouse....and entreat her...godly and favorably."177 The next month, a man was found guilty of repeatedly harassing and slandering a number of burgh residents and was fined by the council, but not ordered to repent in church. ${ }^{178}$ Therefore, it appears that the council's adherence to the national Kirk's policy on repentance was spotty, particularly regarding non-violent cases, although it did not hesitate to step in as the authority over cases that would later fall under the jurisdiction of the kirk session. Like many other measures of reform, Aberdeen's civic officials chose to cherry pick those policies that would underscore their power, not be contentious with conservative residents, and appease leading Protestants. This topic of Aberdeen's kirk session will be discussed at length in the following chapter.

${ }^{174}$ Extracts from the Council Register, 330-331.

175 Extracts from the Council Register, 352.

176 Graham, 60; Margo Todd, The Culture of Protestantism in Early Modern Scotland (New Haven: Yale University, 2002), 128, 156.

177 Extracts from the Council Register, 345.

178 Extracts from the Council Register, 346. 
The flurry of council activity that occurred in 1562, which included the sale of the kirk work, a royal visit, and the establishment of a kirk session, did not carry over into 1563 or, indeed, through much 1568 . Indeed, White has found that the burgh records indicate "only vague tremors" of the political and religious activity that was occurring in the south. Even the tumult of 1567 did not receive more than a passing mention. ${ }^{179}$ Rather, the council returned to exerting its energy over the day-to-day political and economic affairs of the burgh. Those matters concerning religion and the kirk that do appear in the council register indicate a pattern of everyday and practical concerns, particularly in regards to administering the chaplains and their rents.

Although Aberdeen was relatively isolated from the turmoil of 1567, the burgh increasingly felt the squeeze between Huntly and his support for the queen and James Stewart, the earl of Moray and his support for King James. In January 1568, Provost Menzies, apparently in an attempt to balance the burgh's earlier support for Huntly, ordered the removal and sale of the roof lead from St. Machar's Cathedral, despite the loud protestations of a number of leading conservatives; the proceeds were to be sent to the King's cause. Cunningly, Menzies stipulated that residents were prohibited from participating in the removal under the pain of banishment. ${ }^{180}$ Similar to the approach taken in January 1560, Menzies and the council sought to distance the burgh from any

\footnotetext{
179 White, "Religion, Politics and Society in Aberdeen," 230, 231-232.

180 Aberdeen Council, Baillie and Guild Registers, vol. 26, fo. 492; White, "Religion, Politics and Society in Aberdeen," 234-235.
} 
direct involvement in the action and to absolve themselves from any direct responsibility.

Another measure presumably designed to appeal to Moray was the resurrection of the kirk session in late March 1568. Notably, there are fewer members listed than in 1562/1562 session, down to fourteen from twenty-one, which indicates either the haste in which the session was assembled and/or the decline in interest to serve for whatever reason, perhaps as a form of protest in light of the St. Machar's incident. ${ }^{181}$ In any case, the session only survived for two months, although it did handle thirteen cases as opposed to the one in $1563 .{ }^{182}$ Despite the council's best efforts to remain neutral, the burgh was occupied by Huntly and his forces from August 1568 to May 1569, when Huntly was forced to yield to Moray. ${ }^{183}$

The matter of St. Machar's illustrates how little progress Protestantism had made in the burgh since March 1560, when Aberdeen declared for the Congregation. When compared to zealous Protestant burghs such as St. Andrews, the contrast is especially vivid. Whereas St. Andrews effectively became Protestant in the course of one day in June 1559 and certainly "exhibited the features of a fully Reformed Church" five years later, Aberdeen exhibited a Protestant gloss and Catholic foundation through the 1560 s. ${ }^{184}$ While it is clear in retrospect that 1560 marked the

\footnotetext{
${ }^{181}$ CH2/448/1/19, Aberdeen Kirk Session Minutes, Scottish Documents, http:// www.scottishdocuments.com/, downloaded 4/30/11.

${ }^{182}$ CH2/448/1/21-25, Aberdeen Kirk Session Minutes; Graham, 63. The 1568 kirk session will be discussed in more detail in the following chapter.

183 White, "Religion, Politics and Society in Aberdeen," 238, 240.

184 Dawson, "'Ane Perfyt Reformed Kyrk,"' 415, 413.
} 
national transition to Protestantism, the reluctance of Aberdeen's leading authorities to implement reform suggests that they held hope for the return of Catholicism or at least a slow demise. Moreover, it is arguable that the burgh was not concerned with the official religion of the realm, just as long as it was able to retain autonomy and authority over its religion.

This concern for authority is one of the dominant themes that is apparent in Aberdeen's records. In its condemnation of the attacks on religious houses in June and December 1559, the council decried that the offenders were acting without authority and against the law of the realm. Conversely, David Mar argued in January 1560 that the burgh's support for the Congregation would, in fact, be in the interest of the national authority and security. While his underlying motives were likely religious, Mar understood what approach would be most effective in winning over the largely conservative council and, therefore, presented the matter of aligning with the Congregation as a strategy designed to support political stability and safeguard local power. Significantly, Mar's rationalization was echoed by Provost Menzies and the town council's declaration for the Congregation in March 1560. By joining the Congregation, it claimed, the burgh and the nation would be defended and protected. After the Protestant's victory in the summer of 1560 , Aberdeen returned to defending its own authority over that of regional and national powers. Furthermore, as Allan White has shown, the oligarchy's "grip on the government of the burgh" was strengthened after the Reformation as its upper tiers closed ranks in order to effect a 
more-concentrated unity. ${ }^{185}$ By deftly maneuvering through the twists and turns of the Reformation and its immediate aftermath, therefore, Aberdeen's authorities were successful not only in retaining relative local autonomy, but also in restricting the pace and determining the character of reform within the burgh.

${ }^{185}$ White, "Impact of the Reformation on a Burgh Community," 90. 


\section{Chapter Three: Interpretation of Reform}

As discussed in the previous chapter, the kirk session of Aberdeen was rather hastily established in November 1562, partly in response to the new political landscape brought by the fourth earl of Huntly's downfall. Although the creation of the session catered to the wishes of the national government, and Lord James Stewart in particular, its religious views and policies did not necessarily fall in line with the reformed thought as found in burghs such as St. Andrews. As with so many other aspects of Aberdeen's actions, the burgh sought to maintain independence in its religion while meeting the demands, albeit at a minimum, of regional and national interests, which were often greatly divergent. This chapter will use the burgh's limited kirk session records of 1563 and 1568 to examine its authorities' interpretation of reform and compare it with national interpretation as expressed in the Book of Discipline and the legislation of parliament. In order to highlight certain aspects of Aberdeen's religious conservatism contained in its kirk session legislation, additional comparison with St Andrews, arguably the burgh to most embody the Book of Discipline, is provided. The conclusion from the analysis is that the chief aim of Aberdeen's kirk session was to placate external secular and religious authorities by meeting the minimum of their expectations and to preserve as much as possible traditional Catholic practices. By seeking continuity and commonality between Catholicism and Reformed Protestantism, the session was able in the 1560s to achieve 
its desired results. Furthermore, because the session and town council members were practically one and the same, the session capitalized on the opportunity to increase the purview of the town council.

Following Aberdeen's formal alignment with the Congregation in the spring of 1560 , the burgh's next major step in evincing its commitment to the new religion was the appointment of a Protestant minister. Although the Book of Discipline called for the public election of ministers by their future flocks, the initial appointments in many parishes were conducted by parish representatives during the Reformation Parliament in Edinburgh in August 1560. ${ }^{186}$ The selected minister for Aberdeen was Adam Heriot. A former Augustian canon at St. Andrews, Heriot became the minister for the same parish at some point during 1559 and may have been among the canons who publicly renounced Catholicism earlier in the year as Knox mentioned in a letter written in June 1559. In his History of the Church of Scotland, written in 1625, John Spottiswoode described Heriot as an "eloquent preacher" and "greatly beloved...for his humane and courteous conversation." In perhaps a foreshadowing of Heriot's temperament as Aberdeen's minister, Spottiswoode relays that, before his official move to Protestantism, he amended a sermon regarding the subject of real presence so as not to offend the Queen Regent who was to be in the audience. This willingness to

${ }^{186}$ First Book of Discipline, 174; John Knox, The History of the Reformation of Religion in Scotland, ed. William McGavin (Glasgow: Blackie, Fullarton,1831), 206; White, "Religion, Politics and Society in Aberdeen," 165-166. 
not rock the boat must have appealed to Aberdeen's parishioners. ${ }^{187}$ As discussed in the previous chapter, after joining the Congregation, Aberdeen's officials were keen to retain royal favor in order to help preserve autonomy in burgh affairs. Given that Lord James was the commendator of the St. Andrew's priory, the selection of Heriot by the commissioners appears to be a political gesture of good will. ${ }^{188}$ Furthermore, although Heriot may have held sincere Protestant convictions, the records do not indicate that he aggressively attempted to transfer them to his Aberdeen parishioners and, as Allan White has noted, he was likely tightly controlled by the parish elite. ${ }^{189}$ Therefore, from the point of view of the burgh establishment, Heriot was an ideal minister who satisfied the demands of the national Kirk, but did not press his parishioners to reform. With the establishment of Aberdeen's kirk session in November 1562, the provost, fourteen elders, and seven deacons officially joined Heriot in administering kirk matters. Like ministers, elders and deacons were supposed to be nominated and elected by the congregation and were to be "of best knowledge in God's word and cleanest life, men faithful and of most honest conversation," as stipulated by the Book of Discipline. ${ }^{190}$ In Aberdeen, however, they were chosen without public review by the minister, undoubtedly directed by Menzies and other parish elite in keeping with

\footnotetext{
187 John Knox, The Works of John Knox, Volume 6, ed. David Laing (Edinburgh, 1864), 26; David Hay Fleming, ed., Register of the Minister, Elders and Deacons of St Andrews 1559-1600, vol.1 (Edinburgh: Scottish Historical Society, 1889), 3n; John Spottiswoode, The History of the Church of Scotland (1655; reprint, Menston: Scolar Press, 1972), 274.

${ }^{188}$ Donaldson, 80.

189 White, "Religion, Politics and Society in Aberdeen," 166,169.

${ }^{190}$ First Book of Discipline, 174.
} 
the town's oligarchic system. ${ }^{191}$ The most influential quality possessed by eleven of the selected elders was current membership on the town council. The three other elders and all of the deacons were high ranking members of the business community. Furthermore, White has determined that only four of the session members had Protestant sympathies prior to 1560 , with David Mar being the far most visible and vocal proponent. ${ }^{192}$ The primary function of elders was to assist the minister in presiding over cases of parishioner misconduct and admonish each person found guilty of being a "licentious liver." 193 Although a purely secular position in theory, Margo Todd observes that elders "occupied at least semi-clerical status that...conferred spiritual authority," which presumably was not an unwelcome development among Aberdeen's elders. ${ }^{194}$ Deacons were charged with collecting rents and alms for church and redistributing them in the form of charity as determined by the minister.

Occasionally, deacons could also be called upon to assist in session cases, which gave them at least some authority over their fellow parishioners and some influence over the character of the session as a whole. ${ }^{195}$

The first order of business for the kirk session was to establish its function, duties, and officials, which it outlined in its opening legislation. Because the session was so closely linked with the town council, these measures indirectly broadened the

\footnotetext{
191 John Stuart, ed., Selections from the Records of the Kirk Session, Presbytery, and Synod of Aberdeen (Aberdeen: Spalding Club, 1846), 3; White, "Religion, Politics and Society in Aberdeen," 170.

192 White, "Religion, Politics and Society in Aberdeen," 170.

193 First Book of Discipline, 175.

194 Todd, 370.

195 First Book of Discipline, 178-179.
} 
authority of the council. One of the more striking consequences of the kirk session system is that the elected elders and deacons, who were laymen, replaced the clergy as arbiters of moral as well as spiritual behavior and this development is reflected in the relevant Aberdeen session entry. In their weekly meetings, Aberdeen's session members were charged to assess "all faults and offenses" of "Christ his people" of the parish, including themselves, and apply appropriate "reformation and amendment...as God's blessed work requires."196 From the outset, therefore, the kirk session members embraced their new position of power in the parish, adding to their authority as town council members, especially as most of the duties of the session involved implementing laws and administering punishment for transgressions. Although the caveat that "they will answer to God" in one sense holds the session accountable for the actions of parishioners, it provides the session a degree of autonomy as well. ${ }^{197}$ In theory, the congregation had some control over the session in that it elected the officials, but, given that the town council had a long-established hold on the burgh, any lobbying by the congregation against session opinion would likely have been ignored. Thus, in many respects, the session was more of an extension of the town council rather than an independent body fully in the service of the Kirk.

One matter that demonstrates this extension and, simultaneously, the religious values of council members is that of the the upkeep and maintenance of St. Nicholas. After the Reformation, kirk maintenance became the responsibility of the kirk session,

${ }^{196}$ Kirk Session of Aberdeen, 4.

${ }^{197}$ Kirk Session of Aberdeen, 3. 
but, since Aberdeen's kirk session was essentially defunct during the $1560 \mathrm{~s}$, the responsibility fell to the town council. ${ }^{198}$ In January 1563, a kirk keeper was hired by the session and granted payment of fees received for the preparations for baptisms, burials, and marriages and, in May 1564, the town council awarded him a yearly salary of four merks. ${ }^{199}$ Some fifteen months later, he was replaced after committing a few unnamed offenses, and the respective entry indicates the level of concern by council members regarding kirk maintenance. Not only was the salary raised to ten merks per annum, but the council specified that burials within the kirk be arranged by the master of the kirk work as well. ${ }^{200}$ This importance placed on kirk burials was reiterated in June 1567 when the council was seeking to raise a tax to fund repairs to the kirk which was "in diverse parts...ruined and presently [in] decay." Above any interests of appearance, the council asserted that St. Nicholas was the parishioners' "principle place of convention to recognize their God, and to there the teaching of his word, in like manner the sepulcher of their forebears."201 From this phrase, the inclusion of "teaching his word" is arguably the least valued of the three given reasons and the last seems unconnected with the previous two, which points to the continued worth placed on proper and strategically-located burials. Although not expressly banned by the General Assembly until 1581, kirk burials were implicitly forbidden by the Book of Discipline, because, as Todd discusses, the building was intended as a

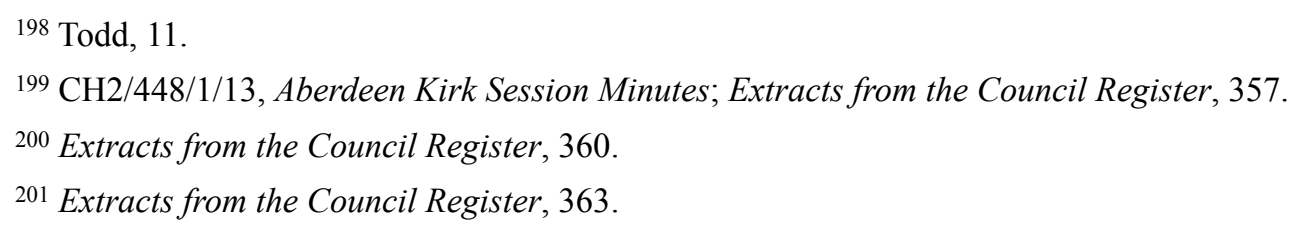


"house of prayer and preaching" and not a venue for idolatry. She observes that the "utter failure of this effort" was because the psychological bonds between a good burial and eternal care for the soul were too strong to break. Additionally, place of burial, especially inside the kirk, had long doubled as a status symbol, demonstrating the wealth and prominence of an individual and, in turn, his ancestors and descendants. ${ }^{202}$ Therefore, this particular trait of Aberdonian religious practice was not unique, nor was the attention to kirk repair, but it is worth noting that some elevenhundred merks were raised for the project, which illustrates the council's commitment to continuing religious tradition, although couched in Protestant values.

Returning to the kirk session, the session produced at its second meeting on 10 December 1562 a pared-down declaration of faith and laid down various statutes governing behavior. Although the theology behind the statutes is nominally Protestant, its foundation in the Ten Commandments suggests that the session sought undisputed common ground between Protestantism and Catholicism in order to effect a guiding theology that would cause the least offense. Indeed, controversy would hardly ensue over assertions such as "the omnipotent, immortal, and eternal...God, the Creator and Maker of heaven and earth, and all that therein."203

Michael Graham views this invocation of the Ten Commandments as nothing more than a simple "endorsement" of elemental Christine doctrine. ${ }^{204}$ However, there

\footnotetext{
202 Todd, 333.

${ }^{203}$ Kirk Session of Aberdeen, 4.

${ }^{204}$ Graham, 61.
} 
is evidence that the session members, who were Catholic for the most part, consciously and deliberately structured the legislation around the Ten Commandments. Firstly, it is unlikely that the session would have devoted much time and energy to "laboriously" recording fundamental doctrine if the goal was simply to satisfy the demands of the national Kirk and leading Protestants. ${ }^{205}$ If that was the case, the session could have simply stated the Ten Commandments and added a brief description of the appropriate punishments for transgressions. Instead, the session chose to elaborate on the meaning and, in some cases, the reasoning of each Commandment, albeit concisely, and provided in most cases an explanation of why the prescribed punishment was appropriate. This approach is tidily demonstrated by the fourth statute of the session's initial legislation regarding the fifth Commandment's requirement of obedience, which was cited by the session as the Scriptural basis for its and other bodies' authority and will be discussed at length later in this chapter in order to demonstrate how it undergirds the other legislation.

Secondly, and more importantly, the session's use of the Ten Commandments testifies to Catholic continuity as it fits in neatly with the Europe-wide preReformation trend of replacing the Seven Deadly Sins with the Commandments, as asserted by John Bossy. Mentioned in Scripture in one form and recognized in another form as doctrine for well over a millennium, the use of the Seven Deadly Sins as the foundation for the Western "moral tradition" was being eroded by the fifteenth century,

205 Lynch and DesBrisay, "The Faith of the People," 294. 
Bossy argues. $^{206}$ The two main factors that led to this decline were the continued disagreement over the hierarchy of sins and the "advent of the catechism," which lent itself more readily to the understanding of the Ten Commandments since they were "easier and more congenial to explain than the seven deadly sins."207 Scotland's role in this shift towards the Ten Commandments is illustrated by St. Andrew's Archbishop John Hamilton's 1552 vernacular catechism, which was one product of the Church's efforts for internal reform during the 1550s. ${ }^{208}$ Michael Lynch and Gordon DesBrisay note that the catechism's "'true and faithful interpretation' of the Commandments" likely served as a template for the Aberdeen kirk session's initial legislation. ${ }^{209}$ Indeed, the session states that the Ten Commandments contain "all that [God] wills his people to do, and what to leave undone," which is similar to the Catechism's explanation that "they are given to us of God and declares to us his godly will," and the 1560 Protestant Confession of Faith's assertion that they "expressed what the things are that please [God]. ${ }^{210}$ Thus, the use of the Ten Commandments as the framework for Aberdeen's moral code manifested in its legislation suggests that the

\footnotetext{
206 John Bossy, Christianity in the West 1400-1700 (Oxford: Oxford University, 1987), 38. St. Thomas Aquinas' definition and explanation of the seven capital vices, which became the standard for medieval Catholic theology, drew partly from Scripture, but relied heavily on Pope Gregory I's discussion in The Moralia in Job. See Thomas Aquinas, Summa Theologica, vol. 2, trans. Fathers of the English Dominican Province (New York: Cosimo, 2007), 964; Louis Bouyer, Dictionary of Theology, trans. Rev. Charles Underhill Quinn (Tournai: Desclee, 1965), 413.

207 Bossy, 120.

${ }^{208}$ Dawson, Scotland Re-formed, 187.

${ }^{209}$ Lynch and DesBrisay, "The Faith of the People," 295. Traces of the Seven Deadly Sins are evident within the expositions of the Ten Commandments, which suggests that they retained some theological and cultural relevance. See John Hamilton, The Catechism, ed. Thomas Graves Law (Oxford: Clarendon Press, 1884).

${ }^{210}$ Kirk Session of Aberdeen, 4; Hamilton, Catechism, 28; A1560/8/3, The Records of the Parliaments of Scotland.
} 
session members were following in the developing tradition of the Catholic Church that was also the cornerstone of the various Protestant doctrines. Therefore, to dismiss the legislation as an obligatory nod to the reformed Kirk ignores the reality of the Catholic shift towards the Ten Commandments. Rather, the use of the Ten Commandments neatly satisfied both sides of the confessional divide and were expertly employed by the Aberdeen kirk session.

In a similar vein, the declaration in the opening statement of faith that God "alone [is] to be feared, served, worshipped, and honored," which echoes the first Commandment, is suitably vague enough to be in compliance with both Catholic and Protestant doctrines. ${ }^{211}$ What is missing from this statement and its accompanying causes is any mention, and subsequent denunciation, of saints or other individuals possessing intercessory powers. These omissions are particularly evident when the text is contrasted with the numerous declarations of faith found in the kirk session registers of St. Andrews, which was the leading Protestant burgh. For example, John Grierson, a former prior of the Predicant Friars in Aberdeen, stated in his recantation at St. Andrews in March 1560 that "we have no command of God bidding us pray to any saints that are departed, but only to him who is Saint of all saints viz. Christ Jesus, our only Saviour, Mediator, and Advocate...perpetually making intercession to his Father, for all his faithful people." 12 Given that Aberdeen had a long history of strong devotion to saints, partly evidenced by the thirty altars in St. Nicholas, there was a

\footnotetext{
${ }^{211}$ Kirk Session of Aberdeen, 4.

${ }^{212}$ Register of St Andrews, 16n, 17.
} 
need for the kirk session to provide an assertion of the primacy of God while conveniently neglecting to discredit the Catholic doctrine on saints.

The opening declaration of faith also calls for the sincere preaching and teaching of "God's most holy work" and "blessed word." Again, this statement falls in line with sixteenth-century Catholic and Protestant practices and is not particularly meaningful in itself. What is striking is the warning that God's vengeance would be "provoked to fall upon his people" unless these practices were dutifully carried out, especially in light of the "many grievous and heinous crimes" committed in the past by the burgh's residents. The offenses alluded to are not related to the "idolatrous" doctrines and practices of Catholicism that would be expected in a Protestant statement of faith, like the Mass and the belief in purgatory, as cited by John Grierson in his recantation. ${ }^{213}$ Rather, it is implied that the crimes were of "manners," such as not punishing sins quickly enough, rather than thoughts or beliefs. Once again, the session is asserting its jurisdiction over behavior so that vice may soon be extirpated and the town could escape "God's scourge and heavy plagues." 214 Although the session sought to silence the "adversaries of...the true religion," it appears that it was largely concerned with deed rather than thought. ${ }^{215}$ Of course, the session avers that it functions to the "glory of God" for the "salvation of...souls," but it places the emphasis in its legislation on external behavior rather than internal belief. ${ }^{216}$ While the religious

\footnotetext{
213 Register of St Andrews, 17.

${ }^{214}$ Kirk Session of Aberdeen, 4.

${ }^{215}$ Kirk Session of Aberdeen, 5.

${ }^{216}$ Kirk Session of Aberdeen, 4.
} 
and civic leaders of St. Andrews sought approved instruction of God's word to instill correct doctrine, which would ensure a "uniformity of faith," and to produce "high standards of public morality," as Jane Dawson affirms, Aberdeen's leaders were chiefly concerned with proper behavior for the good of the community rather than individual adoption of the "true doctrine of the Church."217

While the first statute of Aberdeen's kirk session legislation appears to be a concession to Reformed belief, it is not explicitly so and could, with some theological reasoning, be in compliance with Catholic doctrine as well. Relating back to the statement that only God is to be worshipped, this statute holds that all prayer must be directed to God and any "pardon or remission of sins" must be "obtained...through and by the passion of Jesus Christ." Furthermore, only through Christ's merit will "any work of their own or others...merit or deserve pardon from the wrath of God for sin."218 The Hamilton Catechism affirms a similar principle: "it is God only that by his own proper power and virtue gives grace" and "to God, therefore, only we should pray as giver of all goodness." 219 Thus, the doctrine espoused in this legislation was thoroughly Christian, but vague enough to be easily attributable to either Protestant or Catholic understanding of salvation.

\footnotetext{
217 Dawson, "'Ane Perfyt Reformed Kyrk,"' 428. This concern for "defending the true doctrine" by St. Andrews' leaders is particularly evidenced by the kirk session's diligence in seeking public recantations, genuine or otherwise, from "those who had been heavily identified with the Catholic Church, namely priests and monastics. See Dawson, "'Ane Perfyt Reformed Kyrk,"' 428-429.

${ }^{218}$ Kirk Session of Aberdeen, 5.

${ }^{219}$ Hamilton, Catechism, 277.
} 
The punishment for "persistently and stubbornly" believing contrary to these affirmations, which could, in the kirk session's opinion, only apply to non-Christians, was not only excommunication from the Kirk, but banishment from the parish as well. Only after genuine renunciation of such "heathen" beliefs and penance would the offender be allowed to return. To ensure that banishment was carried out, this piece of legislation also initially decreed that any member of the parish who was caught keeping "company" with the guilty, except in aid of "the reconciliation and winning of them to God," would be made to "ask forgiveness of God" and their fellow parishioners and fined twenty shillings if they could afford it. If they continued in their association with idolaters, they faced excommunication themselves. ${ }^{220}$ However, this last section of the statute was crossed out at some point, presumably because, if "heathen" was taken to mean "Catholic," which most of the burgh's residents were, enforcement would be unrealistic. ${ }^{221}$

Excommunication and banishment were powerful weapons at the Kirk's disposal and were used as penalties for a variety of offenses, as will be later noted. An excommunicant was allowed to remain within the community, but was effectively removed "from the life of the community" as fellow residents were prohibited from any interaction with the offender, including socializing or conducting business. ${ }^{222}$ Banishment was altogether more severe as the offender would forfeit "home, business

\footnotetext{
${ }^{220}$ Kirk Session of Aberdeen, 5.

221 Graham, 61.

222 Todd, 11-12.
} 
and all social connections."223 Thus, the use of these punishments by Aberdeen's kirk session was reserved for the most grievous crimes, most frequently relating to immorality and bad behavior, and banishment was enforced in just one of the thirteen cases to go before the session in the $1560 \mathrm{~s}$.

The remaining statutes in the legislation all pertain to regulating behavior and, like the first statute, are rooted in the Ten Commandments. The second statute enacts the third Commandment, which prohibits blasphemy, either by taking the "name of God in vain," cursing, or taking an oath, except when ordered by "a judge...to declare the truth."224 Since session members were unable to monitor each parishioner's behavior constantly, it expected each household to enforce this statute in private by establishing a "swear jar" of sorts. Upon swearing, the offending household member who was "potent to pay silver" was to contribute a "hardhead" to the household collection, which would later be given to the poor. Those who could not afford the fine, namely servants and children, were to receive a "palm upon the hand" for each offense. Those who swore in public were to be fined seven pence or "be put in cuckstool or pillories." Similarly, "open and manifest blasphemers of God's name" were sentenced to the cuckstool and made to wear on their head a paper crown with the offense written on it. ${ }^{225}$ Serial blasphemers faced banishment. ${ }^{226}$

\footnotetext{
223 Todd, 174.

224 The numbering and order of the Ten Commandments here is that used by Reformed Protestant Churches. See MacCulloch, The Reformation, 710-711.

225 Kirk Session of Aberdeen, 6.

${ }^{226}$ Kirk Session of Aberdeen, 6.
} 
The prescription of the cuckstool, also known as a stool, pillar, place, or seat of repentance, was an ubiquitous innovation of the Reformation and resulted from the Kirk's policy of public repentance. ${ }^{227}$ Although repentance was no longer considered a sacrament, meaning that the act had no power to affect salvation, the Book of Discipline required those who had committed sins in public, which included sexual offenses, to confess, repent, and be admonished by the congregation in public on a regular day of convening. Because individual sins were seen as offenses against God as well as the entire community, public repentance served not only to punish the offender and make him "feel how far he has offended God," but also to name "what slander he has raised in the church" and to warn against other would-be offenders. Crucially, if the offender had offered genuine repentance and fulfilled his punishment, the congregation was enjoined to pray for the offender and openly welcome him back into society, since they should not be more "severe than God declares himself to be."228 This system of repentance and acceptance, therefore, not only served as tools to reduce occurrences of sinful acts and strengthen the bonds of community, but was also, as Todd observes, at the core of "basic Christian beliefs about sin, repentance and divine forgiveness, and of basic Calvinist beliefs about the elect and the reprobate."229 Designated spots for penitence in church had been in use for centuries before the Reformation, with penitents often standing in front of the high altar during

\footnotetext{
227 Todd, 131.

${ }^{228}$ First Book of Discipline, 168.

${ }^{229}$ Todd, 168-169.
} 
Mass. ${ }^{230}$ The cuckstool in kirk, however, was specifically designed to accommodate the new philosophy and procedures of repentance. In the form of a stool or bench that could easily support a handful of people, the cuckstool was generally placed directly below the pulpit facing the congregation. To ensure visibility and underscore godly separation, some cuckstools were placed on an elevated platform and/or distanced far enough from the congregation that the empty space was distinct and intentional. ${ }^{231}$ The cuckstool appears to have been enthusiastically adopted in St. Nicholas as an English visitor remarked in 1636 in his notes on the high visibility of the repentance stool and an Aberdeen parishioner who witnessed the repentance of the earls of Huntly and Errol in 1597 in front of a packed congregation observed that "'the greatest part of the body of the kirk [was] empty before the pulpit."'232

Aside from sitting on the cuckstool during the sermon, public repentance involved several further actions and, as Todd has detailed, the process was "scripted as well as choreographed." In short, after the sermon, the minister called upon the sinner to confess his crime, ask forgiveness from God, the congregation, and, if appropriate, the aggrieved party, and promise to live uprightly henceforth. ${ }^{233}$ Although repenters generally confessed in their own words in the years immediately following the Reformation, scripted confession by elders became increasingly common. ${ }^{234}$

\footnotetext{
230 Todd, 132.

231 Todd, 132-133.

232 Todd, 132n, 133.

233 Todd, 156.

${ }^{234}$ Todd, $157-158$.
} 
Additionally, kneeling for confession was the usual posture, which symbolized inferiority and unworthiness, especially in the presence of the repenter's peers. ${ }^{235}$ Clothing worn by the repenters, too, carried meaning and significance. As mentioned above, the Aberdeen kirk session required convicted blasphemers to wear a paper hat so that the congregation would be in no doubt as to the sin committed. ${ }^{236}$ Additional requirements of repentance, such as standing at the kirk door and public reconciliation, will be discussed in subsequent sections.

Although the third Commandment and, in turn, the third statute prohibits "all laboring and handiwork" on the Sabbath, the statute was not as comprehensive as in other parishes or as directed by the Book of Discipline. ${ }^{237}$ Not only must the whole of Sunday be "kept free from all exercise of labor," as the Book states, but proper activity must be observed for the entire day. Following morning services, children were to be catechized in the presence of the rest of the congregation and, if no services or catechisms were held, then all were to only use the time for prayer and other spiritually reflective activities. ${ }^{238}$ If the Sabbath was kept properly, then "'the soul will win into Christ's bosom."'239 If breached by "profane activity," then it was considered "an offence directly against God as well as kirk and community." As Todd considers, this "strictness" for the Sabbath "was nothing if not a veneration of time set apart by

\footnotetext{
235 Todd, 150.

236 Todd, 147.

${ }^{237}$ Kirk Session of Aberdeen, 6.

${ }^{238}$ First Book of Discipline, 181. Catechism generally included the memorization and, ideally, understanding of the Creed, Ten Commandments, and the Lord's Prayer. See Todd, 272.

239 Todd, 343.
} 
divine commandment for holy exercise." 240 As Reformed Protestantism reduced the number of holy days, the sacredness of the Sabbath increased and, therefore, the negative consequences for violating that sacredness likewise increased. ${ }^{241}$

In Aberdeen, however, the kirk session appears to have sided with Catholicism's more lax approach to what constituted proper Sabbath activity. The statute concerning the Sabbath is rather vague in comparison to the Book of Discipline as it only specifies refraining from work "in time of prayers and preaching," which are assumed to take place in the morning. ${ }^{242}$ Furthermore, the Book of Discipline stipulates that "every notable town" hold mid-week services in addition to those on Sunday and all must refrain from labor during the time of the sermon. ${ }^{243}$ Although Aberdeen established weekly services, it only required the attendance of the elders and deacons, who were to be fined six pence for every absence. Still, it is clear that the session took Sabbath observance seriously, at least on its own definition of proper observance. Although Scripture demanded death for Sabbath breakers, the session lamented that it had no such authority and, instead, mandated that those who were caught laboring were to be fined two shillings and those who skipped Sunday services were to be fined six pence. ${ }^{244}$ What is demonstrated by this particular statute, therefore, is Aberdeen's molding of high-level Protestant policy to accommodate local

\footnotetext{
240 Todd, 342.

241 Todd, 341.

${ }^{242}$ Kirk Session of Aberdeen, 6.

${ }^{243}$ First Book of Discipline, 181.

${ }^{244}$ Kirk Session of Aberdeen, 6.
} 
attitudes while remaining within the broader requirement. Indeed, a crackdown of sorts on Sabbath-breaking only occurred at the order of Regent James Douglas, the earl of Morton, in 1574 and, even then, only six (or 1.5\% of total cases) Sabbathbreaking cases went before the session in Aberdeen for the period 1573-1578 as compared to thirty-three $(14 \%)$ in St. Andrews. ${ }^{245}$

In addition to purely religious activity, the kirk session established legislation that spoke to practical matters as well. With the abolition of the Catholic Church, the traditional system of providing charity disappeared as well. ${ }^{246}$ Although historians debate whether or not this disappearance disadvantaged poor relief as a whole, there is certainly no doubt that many of the traditional sources of funds (monastic charities, for example) vanished. ${ }^{247}$ As such, it fell to the public and, in some cases, secular authorities to care for the needy. In the absence of a national poor law, the Book of Discipline charged parishes with the task of local poor relief. ${ }^{248}$ Like other European societies, the Book differentiated between the deserving poor (for example, widows, orphans, and the infirm) and the undeserving poor (e.g. beggars and vagrants). ${ }^{249}$ For those in the former category, the Book urged local kirks to take genuine interest and concern for the poor because they were "universally so contemned and despised"

\footnotetext{
245 Graham, 90-91, 118-119.

246 Rosalind Mitchison, The Old Poor Law in Scotland: The Experience of Poverty, 1574-1845 (Edinburgh: Edinburgh University, 2000), 4-6.

${ }^{247}$ Mitchison, 4.

248 The first national Scottish Poor Law was approved by Parliament in 1574 and was more or less a duplication of the 1572 English Act. See Mitchison, 7.

${ }^{249}$ Mitchison, 4, 9.
} 
despite the fact that God had them "commended to our care." Sidestepping the responsibility for producing a guide to administering poor relief, the Book simply assured kirks that "God will show you wisdom, and the means" for providing for the poor. ${ }^{250}$

Part of Aberdeen's solution was to enact a statute that obligated citizens to provide "needful sustenance" to the elderly and the poor. In regards to the former, children who were financially able to support their parent(s) would be "admonished" by the preacher and the kirk officers if their parent(s) were found "begging" and lacking in basic necessities and, if support was not forthcoming, they would be excommunicated. The doctrinal basis for this statute was that "God commands father and mother to be honored," and that he who does not love and care for his parents and neighbors "can not love God." With this understanding, therefore, the responsibility for a hefty piece of social welfare shifted from the Church to individuals, yet still regulated within religious discourse. ${ }^{251}$

However, it seems that at least some consideration was given by the session to "all other decayed poor" who were native-born to Aberdeen, while ignoring non-native supplicants. Like "other godly reformed towns," a census of the poor was commissioned so that "provision may be made," as long as they did not go "begging and crying daily" at the kirk and around town. Unlike the native poor, the residents of Aberdeen were not expected to provide welfare to those who were not born within the

${ }^{250}$ First Book of Discipline, 113.

${ }^{251}$ Kirk Session of Aberdeen, 7. 
burgh. Because of "the great plague of poverty reigning in this country, and scarcity of victuals," the session bemoaned the influx of poor immigrants, especially as many were "sturdy beggars, pickers, and pillagers." Therefore, they ordered that all "foreign beggars" be removed from the burgh and not allowed to be within the burgh's limits for more than twenty-fours hours at a time. Furthermore, residents who harbored these sorts would be punished as well. ${ }^{252}$

In a similar vein to the problem of "foreign beggars," the town evidently had an immigrant population of "suspect persons, of evil fame and report" who, despite "having no occupation," spent "prodigally," roamed the town at night and partook in various vices, such as "drinking, and carding, and dice playing." As they were considered "slanderous" and "dangerous to the common weal," the session ordered them to be registered as itinerants and prohibited from residing in the town for more than twenty-four hours if they were known to be "despairing." Unauthorized return to the burgh would result in being branded on the cheek. Residents who disobeyed the law against harboring previously-banished persons faced banishment themselves. Vices were not unique to immigrants, however, and the Aberdeen kirk session sought to rid the town of drunkenness and gambling. A heavy-handed approach was not the first line of attack, however, and those involved in such vices were to be given "gentle admonition" initially, then be publicly "rebuked in the pulpit" if the bad behavior

\footnotetext{
${ }^{252}$ Kirk Session of Aberdeen, 7-8.
} 
continued. Excommunication, but not banishment, was the last resort and could be lifted if the person demonstrated "open signs of repentance." 253

In an effort to curb violence, the fifth piece of the session legislation sought to remove one type of behavior that often served to escalate conflict into violence: "injurious and evil speech." The doctrinal reasoning for placing flyting, as it was known, under the kirk's jurisdiction was that violence provoked by words could result in murder, which was forbidden by God as expressed in the sixth Commandment. This involvement by the local kirks was greatly needed because feud and other forms of violence were rife in Scotland at this time. ${ }^{254}$ Indeed, Keith Brown argues that violence was more prevalent in Ayrshire, Angus, Aberdeenshire, and the Highlands than in the Lothian/Fife crescent. ${ }^{255}$ Flyting, which generally involved both parties exchanging accusations and insults out in the streets or other public venues, was often the public manifestation of a private quarrel. ${ }^{256}$ Although these incidents may be interpreted on the surface as contempt for public conduct, Todd contends that flyting was used "to force resolution by effectively summoning in the neighbourhood....for mediation." Crucially, a quick response to flyting by the community was valuable in avoiding violent and drawn-out feuding. ${ }^{257}$

\footnotetext{
${ }^{253}$ Kirk Session of Aberdeen, 10.

254 Todd, 228.

255 Todd, 228n; Keith M Brown, Bloodfeud in Scotland 1573-1625: Violence, Justice and Politics in an Early Modern Society (Edinburgh: John Donald Publishers, 1986), 7.

256 Todd, 235-236.

257 Todd, 236.
} 
From the 1562 Aberdeen kirk session, conviction for flyting carried not only pecuniary punishment, but public admonishment as well. For those able to pay, the first conviction would result in a fine of eleven shillings and the requirement that they "ask the injured person pardon before the congregation." This "public ritual of reconciliation," as described by Todd, served to effect a "restoration of order" and helped ensure a lasting untroubled relationship between the parties. ${ }^{258}$ Those who were unable to pay were similarly made to ask in public for forgiveness and say "Tongue you lied." A third conviction would result in banishment, but not excommunication. ${ }^{259}$ In a related statute, the bearing of false witness or slander was prohibited by the session. Unusually, the punishment for slander did not take the offender's financial status into account, which may indicate that it was perceived as a greater crime which necessitated repentance before God. As such, first-time "slanders, backbiters, and railers" were to appear before the congregation and appeal to God for mercy while second-time offenders were to be sentenced to the cuckstool and say "Tongue you lied."260

This last phrase of "tongue, you lied" was a formula used, although infrequently, in Scottish medieval punishments for defamation and gained currency with kirk courts after the Reformation. As studied by Elizabeth Ewan, the specific phrase and accompanying ritual dates from at least 1509 and was formed by a mixture

\footnotetext{
258 Todd, 249.

${ }^{259}$ Kirk Session of Aberdeen, 7.

${ }^{260}$ Kirk Session of Aberdeen, 9.
} 
of ecclesiastical and secular concerns for salvation and communal peace. ${ }^{261}$ In medieval Church doctrine, "'sins of the tongue'" were either folded into the Seven Deadly Sins or treated separately. ${ }^{262}$ In Reformed Protestant doctrine, defamation was directly rooted in the ninth Commandment. The tongue itself was long thought of as having an evil will of its own and to be difficult to control. Moreover, the harm potentially caused by the use of the tongue was often considered more injurious than the sword. ${ }^{263}$ Under command, the tongue yielded speech, "the organ of reason" provided to man by God. ${ }^{264}$ Therefore, by speaking in public "tongue, you lied," the sinner regained control of his tongue. ${ }^{265}$ For the purposes of Kirk law, the language and accompanying ritual of the cuckstool used for flyting and defamation cases was not only a means for the sinner outwardly to indicate regained control of his actions and to repent before God, but also acted as a means of community-building as the congregation collectively forgave the sinner and witnessed a process that they would endure if they sinned likewise. ${ }^{266}$

Returning to Aberdeen's kirk session legislation, Graham and other historians have shown that sexual offenses were often the most targeted by kirk sessions in the

\footnotetext{
${ }^{261}$ Elizabeth Ewan, "'Tongue, You Lied": The Role of the Tongue in Rituals of Public Penance in Late Medieval Scotland," in The Hands of the Tongue: Essays on Deviant Speech, Edwin D. Craun (Kalamazoo: Medieval Institute Publications, 2007), 117. Defamation itself was an excommunicable offense under Scottish Church law from 1225 and also fell under secular jurisdiction from at least 1317. Ewan, 117-118.

262 Ewan, 123.

263 Ewan, 125.

${ }^{264}$ Ewan, 126.

265 Ewan, 124.

${ }^{266}$ Ewan, 118, 119.
} 
immediate decade following the Reformation, and Aberdeen was no different. ${ }^{267}$ In fact, a good deal of the Aberdeen session's opening legislation is dedicated to prescribing penalties for various categories of sexual offenses, which include "adultery, whoredom, and fornication." As with the penalty for Sabbath breaking, the session warned committers of illegal sexual intercourse that the "due punishment of the law of God is death," but, as the penalty has been "negligently ignored and not regarded by all Christian princes," the session was constrained in its prescriptions. It did, however, reserve the power to "purge their town of such rotten members." Thus, the statute calls for the immediate banishment of brothel keepers, prostitutes, and "whoremongerers." This particular statute was obviously one of high priority for the session as the only case to go before it in January 1563 was one Elspet Murray, who was convicted of running a brothel. The record does not indicate if she was given a hearing or an opportunity either to refute the allegation or mend her ways. In any case, she was ordered to be carted through the town within two days and publicly banished.

Likewise, "manifest and openly known" adulterers faced being "carted through the town" and banished. Even suspected, but not proven adulterers, identified by their "evil appearances and unseemliness," were ordered to cease contact with the other suspect and, if they were subsequently seen together, they would be branded "open adulterers" and punished accordingly. ${ }^{268}$ The Kirk's desire for adultery to be

\footnotetext{
${ }^{267}$ Graham, 69.

${ }^{268}$ Kirk Session of Aberdeen, 8.
} 
recognized as a capital offense by law was fulfilled by Parliament in June 1563.

Although the death penalty was to be reserved for repeat offenders, this legislation added to the Kirk's and the session's legal powers. ${ }^{269}$ Ever-concerned with proper sexual activity, Aberdeen's opening session in March 1568 altered the designated punishments for adulterers. On three consecutive Sundays, the offender was to stand at the kirk door at the second bell, barefoot and wearing only a sackcloth and a paper crown. During the sermon, he was to stand at the "place of repentance" (presumably next to the cuckstool) and return to the door as parishioners departed so that he would be a "spectacle to the whole people." 270

This statute demonstrates that the "penitential performance," as Todd observes, was necessary to convey "basic Christian beliefs about sin, repentance and divine forgiveness."271 Although the penitential process was rooted in medieval theology and ritual, it fit neatly with "Calvinist beliefs about the elect and the reprobate."272 In order for these messages to be conveyed properly to both the penitent and the congregation, the ritual elements involved in the performance had to be observed correctly. Like the Aberdeen session's prescription for blasphemers and flyters, but more elaborate, every element in the repentance process for adultery carried easily recognizable meaning. ${ }^{273}$

\footnotetext{
${ }^{269}$ A1563/6/10, Records of the Parliaments of Scotland.

${ }^{270}$ Kirk Session of Aberdeen, 14.

271 Todd, 168-169.

272 Todd, 154, 169.

273 Todd, 129.
} 
Firstly, the tolling of the kirk bells represented the coming together of the godly facing sin and excluding sinners until they repented. ${ }^{274}$ Secondly, the interval between the ringing of the second bell, when most parishioners would enter the kirk, and the ringing of the third and last bell, which marked the beginning of services, was the "'threshold time"' and signified a threshold of change, whereby the offender would enter as a sinner and leave redeemed and forgiven. ${ }^{275}$ As the statute noted, the repenters' station at the kirk door ensured full visibility. Coupled with the location of the repentant during the sermon, this separation from the congregation was great enough to symbolize distance from God and the godly, but close enough to underscore the "pervasiveness of sin and everyone's vulnerability."276 Thirdly, the appearance of the repentant was particularly important for greater offenses like adultery. The sackcloth was particularly humiliating and the bare feet, not normally exposed in public, drew further attention to the "inappropriateness of the sinner's behaviour, an embarrassment to the godly community."277 Combined, these elements made for a powerful "spectacle" that would, in theory, reconcile the sinner to God, the kirk and the community, allow for communal forgiveness of the sinner, and deter would-be sinners. ${ }^{278}$

\footnotetext{
274 Todd, 154.

275 Todd, 150-151.

276 Todd, 175 .

277 Todd, 145, 147.

278 Todd, 130, 181.
} 
This revised act against adultery was immediately put to use as four out of the five cases to go before the March 1568 session concerned adultery. The first was also a case of abandonment, as one William Cryste had left his wife to live with Margaret Myrton and refused to return. Cryste was unapologetic for his actions and he and his "whore" were ordered to be penalized accordingly. ${ }^{279}$ In the other three cases, the sinners more readily confessed their crimes and accepted punishment as adulterers. ${ }^{280}$ From these cases, it is clear that the kirk session was more than willing to enforce the kirk laws regarding adultery, but not those laws that pertained directly to internal religious belief and practice as was prevalent in other burghs. ${ }^{281}$

Similar to the penitential ritual for adultery as decreed in 1568 , but less severe, was the 1563 ritual for convicted fornicators. For the first conviction, an offender was to ask forgiveness not only from God, but also from the "congregation, whom they have slandered," again demonstrating the understanding that individual sins tarnished the whole community in the eyes of God. ${ }^{282}$ Although the language of repentance here is not specified, it is known that repenters confessed in their own words in the early years after the Reformation, but scripted confession, often written by the elders, became more common as some repenters misbehaved and did not take the confession seriously. To reduce the likelihood of a repeat offense, the session would assign a cautioner, a bondsmen of sorts, who would be financially liable if the guilty party was

\footnotetext{
279 Kirk Session of Aberdeen, 13.

${ }^{280}$ CH2/448/1/21, Aberdeen Kirk Session Minutes.

${ }^{281}$ Graham, 90-91, 118-119.

${ }^{282}$ Kirk Session of Aberdeen, 8; Todd, 174.
} 
convicted of fornication a second time. A second conviction was punishable by "carting" and "dunking in the water" and a third by banishment. It is significant that these punishments were in line with those of Dundee, another early reformed burgh, which speaks to the seriousness paid to the matter by Aberdeen's kirk session. ${ }^{283}$

Indeed, the problem of fornication was not just a concern of Aberdeen and other individual parishes, but of the national parliament as well, for parliamentary legislation regarding the penalties for the offense was passed, possibly in December 1564 and certainly in December 1567.284 Because Aberdeen's kirk session was not in operation when the bill was passed, legislation was retroactively added at some point to the 1563 session records. The new imposed penalties were significantly harsher than initially determined: fines were set at $£ 40,100$ merks, and $£ 100$ for each successive offense. If unable or unwilling to pay the fine, jail time with only limited provisions was eight days for first-time offenders, which was doubled, then tripled for repeat offenders. Additionally, first-time offenders were to stand for two hours at the market cross bareheaded and second-time offenders had their heads shaved. A third offense was ultimately punishable by dunking and banishment. ${ }^{285}$

Baptism of children who were the products of "whoredom" was a special concern of the session. ${ }^{286}$ One of the two recognized sacraments of the Scottish Kirk, baptism was heavily guarded against improper and inappropriate administration. The

\footnotetext{
${ }^{283}$ Graham, 49.

${ }^{284}$ A1564/12/4, Records of the Parliaments of Scotland.

${ }^{285}$ A1567/12/13, Records of the Parliaments of Scotland; Kirk Session of Aberdeen, 12.

${ }^{286}$ Kirk Session of Aberdeen, 11.
} 
Book of Discipline's only prohibition of ministering baptism was for children born during the sentence of excommunication of one or both of their parents because the "Sacraments appertain only to the faithful and to their seed."287 The Aberdeen session broadened this prohibition to children born out of wedlock. The 1562 statute banned baptism for illegitimate children unless the father and mother, if she was able, were present, made their repentance, and promised either to marry or keep away from each other's company. ${ }^{288}$ This matter evidently remained a problem because the session felt the need to reiterate the statute in April 1568. Furthermore, it was deemed necessary for fathers to declare to the reader the day before the baptism that the child was conceived in matrimony. ${ }^{289}$ The 1568 legislation also specified that the minister could not baptize an illegitimate child until its parents repented before the congregation during Sunday services. ${ }^{290}$ Through this strict regulation of baptism, the session not only stretched its reach beyond the guidelines of the Book of Discipline, but also superseded the minister's discretion in administering the sacrament as well, arguably more for the reason of broader social control rather than religious discipline. In comparison, the cases concerning baptism of illegitimate children in St. Andrews clearly state that the instructed actions are ordered by the "ministrie," not the

\footnotetext{
287 First Book of Discipline, 170.

${ }^{288}$ Kirk Session of Aberdeen, 11.

${ }^{289}$ Kirk Session of Aberdeen, 14-15.

${ }^{290}$ Kirk Session of Aberdeen, 15.
} 
session. $^{291}$ In some matters, therefore, the minister of Aberdeen's autonomy was severely limited in deference to that of the session.

Another matter in which the session rather than the minister sought to serve as arbiter was handfasting. Handfasting was a long-established Scottish custom, whereby betrothed couples could choose to live together as if they were married. ${ }^{292}$ As the session sought the "eschewing of such fornication," it legislated that engaged couples were prohibited from sex until "they complete the bann." Furthermore, handfasting had often resulted in protracted engagements, "neither for fear of God nor love of their party," and, as such, they were guilty of "manifest fornication and whoredom." Therefore, the session mandated that all current handfasters were to be officially married by the next Shrove Tuesday (5 March 1563). Although the session likewise intended to specify the maximum time span of future engagements, a blank space was left, presumably to be filled in at a later date. In any case, the engagement was to be announced and recorded in church the Sunday following "the promise making." 293 This statute evidently went unheeded as the session reiterated it in April 1568 and added the provision that the minister was not to preside over handfasting contracts. ${ }^{294}$ Like other sexual offenses, the session's anxiety over handfasting indicates its desire to monitor and control the private behavior of its parishioners through kirk discipline.

\footnotetext{
${ }^{291}$ For example, see Register of St Andrews, 226.

292 Todd, 274n; Graham, 122-123.

${ }^{293}$ Kirk Session of Aberdeen, 11.

294 Kirk Session of Aberdeen, 14.
} 
There are many reasons for this great attention to the matter of fornication, as well as other sexual offenses, by both national and local authorities. Graham suggests that religion and economy were the two primary factors behind the "seeming obsession with sex."295 Firstly, illicit sex was condemned across the religious spectrum: "Reformed, half-reformed or unapologetically Catholic." More significantly, sex outside the bonds of marriage risked provoking God's ire upon the whole community. ${ }^{296}$ By particularly targeting illicit sexual activity, therefore, the Kirk could find common ground in all regions of the realm, including Catholic Aberdeen. Secondly, by working to reduce the illegitimacy rate, religious and civic leaders sought to reduce the number of vagrants and those living in poverty, especially "in a context of diminishing resources and growing population." Todd's reasoning emphasizes this aspect of social welfare: in attempting to decrease the number of illicit sex cases, the Kirk sought to ensure firmer foundations for marriage and community godliness in addition to more practical concerns, such as lowering of the illegitimacy rate and the number of single-parent households. ${ }^{297}$ Indeed, she points out that the bastardy rates were lowered remarkably in under a half-century following the Reformation. ${ }^{298}$ Additionally, "strict control of sexual behaviour could prevent worse sin," such as abortion or infanticide. ${ }^{299}$ Finally, Bossy argues that a gradual shift in

\footnotetext{
${ }^{295}$ Graham, 282.

296 Graham, 283.

297 Todd, 291.

298 Todd, 292.

299 Todd, 294.
} 
Catholic concern from charity to sexual ethics had already begun in the sixteenth century, a product of the narrowing authority of the Church in place in the sixteenth century. ${ }^{300}$ In view of Bossy's theory, the Aberdeen kirk session's focus on sexual activity speaks to a general European pattern rather than distinctive movement within Scotland. While the motives behind the session's legislation on sexual activity may not be entirely discernible to historians, the legislation certainly echoes Christian morality and provided a utilitarian means for controlling population growth and social welfare.

As discussed in the previous chapter, Protestantism and most aspects of reform often provoked tension and hostility within the burgh. Therefore, it is not too surprising that its kirk session included a peculiar statute in its initial legislation. In an effort calm the waters, it ruled that "no disputation nor reasoning of scriptures be at dinner or supper or open table" nor any "chiding be at the time of meat." Each offense, presumably enforced on the honor system, was to incur a two shilling donation to the poor. ${ }^{301}$ Similarly, the preacher was prohibited from writing or speaking about sensitive matters or rebuking "any notable or particular person" without authorization of the session. ${ }^{302}$ As Lynch and DesBrisay have noted regarding this prohibition, "the elite had drawn up an insurance policy for its own

\footnotetext{
${ }^{300}$ Bossy, 41-42.

${ }^{301}$ Kirk Session of Aberdeen, 10.

${ }^{302}$ Kirk Session of Aberdeen, 10-11.
} 
preservation. ${ }^{303}$ Moreover, it is indicative of the authorities' anxiety over the strife that could occur as a result of religious sensitivity.

The session also sought to limit abuse against the Kirk. Hence, the session warned that those who "mock...and haw in derision the preaching of the word of God," the preacher or kirk officials, session acts, "persuade the simple" to be disobedient, or do not attend church services, would be punished in the manner adopted by "other reformed towns." 304 Dissenters also had limited ability to bring about prosecution for criminal offenses. An accusation brought forth by a person who did not profess the "true religion," which remained undefined, was to be verified by a known member of the congregation before prosecution would be allowed. If the accusation was unverified, then the accuser was to be punished in the manner assigned to the fault. ${ }^{305}$ With these statutes, therefore, the session sought to minimize the contentious matter of discussing religion in public or even private discourse while protecting the integrity and authority of the Kirk and its members.

Intertwined with all of these statutes is the reassertion and emphasis on obeying authority, whether parental, political, or religious. In the same way that children ought to obey their parents, so too adults should obey "princes, magistrates, and rulers." In return, these figures "should be fathers and mothers to the common wealth, caring and providing for the same." Since God demands obedience to parents

\footnotetext{
${ }^{303}$ Lynch and DesBrisay, "The Faith of the People," 295.

${ }^{304}$ Kirk Session of Aberdeen, 9-10.

${ }^{305}$ Kirk Session of Aberdeen, 9.
} 
in the fifth Commandment, disobedience of earthly authorities equals disobedience of God. As with other statutes, continued disobedience of authority and the law would eventually result in excommunication. ${ }^{306}$ Given the oligarchic political structure of Aberdeen, this statute served to extend and reinforce the fundamental authority of secular officials into the spiritual sphere. Conveniently for Aberdeen's civic and religious leaders, the theme of obedience was prominent within the theology of the new religion. In the Confession of Faith, for example, the authors remind their readers of the failure of Adam and Eve to obey God and Christ's subsequent suffering for man's continued disobedience. Although God "accepts our imperfect obedience," the authors maintain that man must strive to obey him, Scripture, and those "whom God has placed in authority." 307 Furthermore, if "ye declare yourselves God's true and obedient officers," the Book of Discipline declares, then "your commonwealth should be rid of innumerable troubles." 308 Thus, obedience was at least one matter that appealed to the interests of both the leaders of Aberdeen and of the new Kirk.

As demonstrated above, the interpretation of reform by the kirk session of Aberdeen was first and foremost one that attempted to check the boxes of reform expected by higher authorities while not denying Catholic sensibilities. By framing the legislation around the Ten Commandments and focusing on the behavior of parishioners, especially illicit sexual activity, the session was able to employ deftly

\footnotetext{
${ }^{306}$ Kirk Session of Aberdeen, 7.

${ }^{307}$ A1560/8/3, The Records of the Parliaments of Scotland.

${ }^{308}$ First Book of Discipline, 198.
} 
common ground between Catholicism and Protestantism. Conversely, by ignoring points of contention, like the papacy and particular forms of worship and doctrine, as Michael Graham has noted, the session avoided provoking unwanted attention from either side. ${ }^{309}$ The success of this approach is evinced by the demise of the kirk session in early 1563 , just a matter of weeks after its inception, and again in May 1568 after its reestablishment in late March. The external political circumstances necessitating the formal existence of the sessions - the suppression of the fourth earl of Huntly and the presence of Lord James Stewart in the fall of 1562 and Queen Mary's defeat in the spring of 1568 — passed and Aberdeen's officials were once again able to return to their long-held routines and means of overseeing the religion of the burgh. ${ }^{310}$

${ }^{309}$ Graham, 61.

310 White, "Religion, Politics and Society in Aberdeen," 169; Graham, 63. 


\section{Conclusion}

Through the Middle Ages, Aberdeen's ecclesiastical landscape steadily developed and eventually blossomed into one of Scotland's richest sacred settlements. Within a few miles, there were over a dozen ecclesiastical buildings which local residents generously supported. From early 1560 , however, the tangible hallmarks of the burgh's Catholicism were in danger of decay. By the end of the sixteenth century, the majority of the buildings were repurposed, dilapidated, or closed altogether. ${ }^{311}$ The Catholic faith of the burgh's inhabitants, however, did not erode as quickly and Michael Lynch and Gordon DesBrisay have noted that "genuine conversion" to Reformed Protestantism "may have taken generations for some parts of Aberdeen society." 312 When viewed in this larger context, the 1560 s emerge as a critical era of transition in which Aberdeen experienced considerable change as well as continuity. Close study and analysis of the implementation and interpretation of reform by the burgh's leaders in the years following the Reformation reveals a picture of political and religious complexity.

Initially, the burgh was intensely opposed to reform and its resistance is palpable in the town council records. Aside from a brief mention in June 1559 of the tumult occurring in the south, the records of town council indicate that it paid little attention the opening skirmishes of the Reformation, which suggests that it did not feel

${ }^{311}$ Dennison, Simpson, and Simpson, "The Growth of the Two Towns," 28-31.

312 Lynch and DesBrisay, "The Faith of the People," 296. 
that Catholicism was under any serious threat. It was not until a Protestant "congregation" arrived at Aberdeen's doorstep that the council felt the need to comment upon or take action in response to the fighting that had begun a month earlier. ${ }^{313}$ Despite council member David Mar's ephemeral Protestant coup in early January 1560, the burgh did not formally take a side in the conflict until March 1560 when it joined the Lords of the Congregation. ${ }^{314}$ Still, that alliance was motivated by political need, not religious conviction. ${ }^{315}$ Over the course of the next eight years, Aberdeen's authorities grudgingly sold the kirk work from St. Nicholas, acquired the friaries, established, dissolved, and re-established the kirk session, and generously made provisions for Catholic ex-clergy, among many other measures. When faced with another bout of national crisis in 1567-1568, the burgh once again remained neutral as it had initially in 1560, and made concessions both to the Catholic George Gordon, fifth earl of Huntly, and Protestant Regent James Stewart, the earl of Moray. ${ }^{316}$ As discussed in Chapter Two, the burgh's reluctance to assent to reform stemmed not only from religious conservatism, but also from the over-arching goal of preserving the ability to self-govern and maintain direct control over its own affairs. Since the burgh was unwilling to implement reform quickly, it invariably invited a battle of wills with the government and the Kirk over the next few decades.

\footnotetext{
313 Extracts from the Council Register, 323-324, 326; White, "Religion, Politics and Society in Aberdeen," 153.

314 Extracts from the Council Register, 315, 322.

315 White, "Impact of the Reformation on a Burgh Community," 92-93.

316 Aberdeen Council, Baillie and Guild Registers, vol. 26, fo. 492; White, "Religion, Politics and Society in Aberdeen," 234-235.
} 
Alongside implementation, the burgh's refusal to abandon Catholicism entirely in favor of Protestantism is illustrated in its kirk session records, especially when the legislation is compared to the directives given in the Book of Discipline. The statement of faith as recorded on 10 December 1562 is worded in such a way as to appear Protestant, but not betray Catholic belief. Taking its cue from the Ten Commandments, which were already favored by the Catholic Church, the kirk session issued legislation on which addressed ills that both Churches could agree on. ${ }^{317}$ By concentrating on the regulation of moral behavior, the session was able to distract attention from matters of religious belief and practice. This approach was successful as the burgh allowed the session to cease operation in January 1563 without immediate and direct consequence. Similarly, the 1568 session was set up in March to curry favor with Regent Moray, but vanished once again in May. Over five years later, at the end of the Civil Wars, the session was resurrected and has endured in one form or another through the ensuing centuries. ${ }^{318}$ Visible in the limited session legislation is the familiar theme of authority and threaded through the legislation is the religious explanation for deferring to authority. Although the directive to obey authority, whether spiritual or temporal, appears in various places in Scripture, the fifth Commandment was handily employed by the kirk session: "God commands father and mother to be honored, comprehending under them all princes, magistrates, and

\footnotetext{
${ }^{317}$ Lynch and DesBrisay, "The Faith of the People," 295.

318 Graham, 63; The Kirk of St Nicholas Uniting, http://www.kirk-of-st-nicholas.org.uk/ourhistory/ millenium.asp, downloaded on 4/30/11.
} 
rulers." ${ }^{19}$ This piece of legislation, therefore, neatly illustrates how Aberdeen's leaders were able in the 1560 s to further their own agenda while meeting the expectations, albeit at a minimum, of external authorities.

Over the next few decades, Reformed Protestantism was slowly implemented. King's College operated as a Catholic institution until 1569 and Catholic ex-clergy were allowed to receive their pensions without formally converting until $1573 .{ }^{320}$ The prohibition against Catholicism was not enforced until November 1573, while strict keeping of the Sabbath was not addressed until October 1576. ${ }^{321}$ The kirk work of St. Nicholas further suffered as a consequence of the visit in 1574 of Regent James Douglas, the fourth earl of Morton. Included in the "purge" were the organ and choir stalls, which were removed, and the statues and crucifixes, which were burned. One new item that was installed was a new repentance stool, which must have been an addition particularly welcomed by the burgh's sinners. ${ }^{322}$ By the 1590 s, the parish employed three ministers and a reader, as necessitated by a rapidly increasing population. ${ }^{323}$ Indeed, the parish was split in 1596 and a partition was erected in St. Nicholas Kirk to accommodate the two congregations. ${ }^{324}$ Thus, by the end of the

\footnotetext{
${ }^{319}$ Kirk Session of Aberdeen, 7.

${ }^{320}$ Graham, 58; Lynch and DesBrisay, "The Faith of the People," 296.

${ }^{321}$ Graham, 63.

${ }^{322}$ Lynch and DesBrisay, "The Faith of the People," 296.

${ }^{323}$ Lynch and DesBrisay, "The Faith of the People," 298.

${ }^{324}$ Lynch and DesBrisay, "The Faith of the People," 298; Dennison, Simpson, and Simpson, "The Growth of the Two Towns," 30.
} 
sixteenth century (some four decades after the Reformation), the foundations of the new Kirk were beginning to solidify in the burgh of Aberdeen.

While this thesis has added to the understanding of Aberdeen's implementation and interpretation of reform in the $1560 \mathrm{~s}$, there are additional aspects that merit further study. For example, primarily due to the difficulty of accessing and examining all of the existing burgh records, this thesis was not able to fold in analyses of the religious factors at play in the matters of Aberdeen's friaries and King's College, which would have used as a starting point Allan White's detailed chronicling of the respective narratives and key characters. Additionally, while Michael Graham has expertly compared the kirk session disciplinary records of Aberdeen and other major burghs, a study of the religious sentiment expressed in these records would shed light on the variations in belief and developing religious identities.

Although a complete study of religion in the burgh of Aberdeen in the 1560s has yet to be produced, the nature of the known surviving sources means that a full revelation of the religiosity of a majority of the burgh's residents, the "common folk," is not possible. ${ }^{325}$ Unlike the kirk session register of St. Andrews for the 1560s, which contains much more explicit expression of religious belief, Aberdeen's registers are comparatively bare and other sources that might express individual belief, such as personal diaries or correspondence, have yet to surface. Nonetheless, this thesis

\footnotetext{
${ }^{325}$ Lynch and DesBrisay, "The Faith of the People," 298.
} 
contributes to scholarship by offering a more-detailed picture than is currently available of the implementation and interpretation of reform in Aberdeen. 


\section{Works Cited}

\section{Primary Sources}

Aberdeen Council, Baillie and Guild Registers. Aberdeen City and Aberdeenshire Archives. CA/1/24, CA/1/26.

Aberdeen Kirk Session Minutes. Scottish Documents Website, http:// www.scottishdocuments.com. CH2/448/1-25.

Aquinas, Thomas. Summa Theologica. Vol. 2. Translated by Fathers of the English Dominican Province. New York: Cosimo, 2007.

Brown, Keith et al., eds. The Records of the Parliaments of Scotland to 1707, http:// www.rps.ac.uk/.

Cameron, James K., ed. The First Book of Discipline. Edinburgh: The Saint Andrew Press, 1972.

Fleming, David Hay, ed. Register of the Minister, Elders and Deacons of St Andrews 1559-1600. Vol. 1. Edinburgh: Scottish Historical Society, 1889.

Hamilton, John. The Catechism. Edited by Thomas Graves Law. Oxford: Clarendon Press, 1884.

Knox, John. The History of the Reformation of Religion in Scotland. Edited by William McGavin. Glasgow: Blackie, Fullarton,1831.

Knox, John. The Works of John Knox, Volume 6. Edited by David Laing. Edinburgh, 1864.

Spottiswoode, John. The History of the Church of Scotland. 1655. Reprint. Menston: Scolar Press, 1972.

Stevenson, Joseph, ed. Calendar of State Papers, Foreign Series, of the Reign of Elizabeth, 1560-1561. London: Longmans, Green, Reader, and Dyer, 1865. 
Calendar of State Papers, Foreign Series, of the Reign of

Elizabeth, 1569-1571. London: Longmans, Green, Reader, and Dyer, 1874.

Stuart, John, ed. Extracts from the Council Register of the Burgh of Aberdeen, 1398-1570. Aberdeen: Spalding Club, 1844.

Selections from the Records of the Kirk Session, Presbytery, and Synod of Aberdeen. Aberdeen: Spalding Club, 1846.

\section{Secondary Sources}

Bardgett, Frank D. Scotland Reformed: the Reformation in Angus and the Mearns. Edinburgh: J. Donald Publishers, 1989.

Bell, Catherine. Ritual Theory, Ritual Practice. Oxford: Oxford University, 1992.

Bossy, John. Christianity in the West 1400-1700. Oxford: Oxford University, 1987.

Bouyer, Louis. Dictionary of Theology. Translated by Rev. Charles Underhill Quinn. Tournai: Desclee, 1965.

Brown, Keith M. Bloodfeud in Scotland 1573-1625: Violence, Justice and Politics in an Early Modern Society. Edinburgh: John Donald Publishers, 1986.

Cameron, Euan. The European Reformation. Oxford: Clarendon Press, 1991.

Cheney, C. R. A Handbook of Dates, For Students of British History, rev. ed. Cambridge: Cambridge University, 2000.

Dawson, Jane E. A. Scotland Re-formed, 1488-1587. Edinburgh: Edinburgh University Press, 2007.

"'The Face of Ane Perfyt Reformed Kyrk': St Andrews and the Early Scottish Reformation." In Humanism and Reform: The Church in Europe, England, and Scotland, 1400-1643: Essays in Honor of James K. Cameron, edited by James K Cameron and James Kirk, 413-435. Oxford: Blackwell, 1991. 
Dennison, E. Patricia. Introduction to Aberdeen Before 1800: A New History. Edited by E. Patricia Dennison, David Ditchburn, and Michael Lynch, 1-10. East Linton: Tuckwell, 2002.

Dennison, E. Patricia, David Ditchburn, and Michael Lynch. Preface to Aberdeen Before 1800: A New History. Edited by E. Patricia Dennison, David Ditchburn, and Michael Lynch, xxv-xxviii. East Linton: Tuckwell, 2002.

Dennison, E. Patricia, Anne T. Simpson, and Grant G. Simpson, "The Growth of the Two Towns." In Aberdeen Before 1800: A New History, edited by E. Patricia Dennison, David Ditchburn, and Michael Lynch, 13-43. East Linton: Tuckwell, 2002.

Diefendorf, Barbara D. From Penitence to Charity. Oxford: Oxford University, 2004.

Donaldson, Gordon. Scotland: James V to James VII. Edinburgh: Oliver \& Boyd, 1965.

Duffy, Eamon. The Stripping of the Altars: Traditional Religion in England, c. 1400c.1580. New Haven: Yale University, 1992.

Ewan, Elizabeth. "'Tongue, You Lied": The Role of the Tongue in Rituals of Public Penance in Late Medieval Scotland." In The Hands of the Tongue: Essays on Deviant Speech, edited by Edwin D. Craun, 115-136. Kalamazoo: Medieval Institute Publications, 2007.

Graham, Michael F. The Uses of Reform: 'Godly Discipline' and Popular Behavior in Scotland and Beyond, 1560-1610. Leiden: E. J. Brill, 1996.

Jones, Colin. The Cambridge Illustrated History of France. Cambridge: Cambridge University, 1994.

Kellar, Clare. Scotland, England, and the Reformation, 1534-61. Oxford: Oxford University Press, 2003.

Lynch, Michael. Edinburgh and the Reformation. Edinburgh: John Donald Publishers, 1981. 
Lynch, Michael and Gordon DesBrisay. "The Faith of the People." In Aberdeen Before 1800: A New History, edited by E. Patricia Dennison, David Ditchburn, and Michael Lynch, 289-308. East Linton: Tuckwell, 2002.

MacCulloch, Diarmaid. The Reformation. New York: Penguin, 2004.

McCallum, John. Reforming the Scottish Parish: the Reformation in Fife, 1560-1640. Farnham: Ashgate, 2010.

Mason, Roger. "Renaissance and Reformation." In Scotland: A History, edited by Jenny Wormald, 107-142. Oxford: Oxford University, 2005.

Mitchison, Rosalind. The Old Poor Law in Scotland: The Experience of Poverty, 1574-1845. Edinburgh: Edinburgh University, 2000.

Ryrie, Alec. The Origins of the Scottish Reformation. Manchester: Manchester University Press, 2006.

Sanderson, Margaret H. B. Ayrshire and the Reformation: People and Change, 1490-1600. East Linton: Tuckwell Press, 1997.

Todd, Margo. The Culture Of Protestantism In Early Modern Scotland. New Haven: Yale University, 2002.

White, Allan. "The Menzies Era: Sixteenth-Century Politics." In Aberdeen Before 1800: A New History, edited by E. Patricia Dennison, David Ditchburn, and Michael Lynch, 224-237. East Linton: Tuckwell, 2002.

"Impact of the Reformation on a Burgh Community: The Case of Aberdeen." In The Early Modern Town in Scotland, edited by Michael Lynch, 81-101. Wolfeboro: Croom Helm, 1987.

"Religion, Politics and Society in Aberdeen, 1543-1593." PhD diss., University of Edinburgh, 1985.

Verschuur, Mary. Politics or religion?: The Reformation in Perth, 1540-1570. Edinburgh: Dunedin Academic, 2006.

Walsham, Alexandra. Charitable Hatred: Tolerance and Intolerance in England, 1500-1700. Manchester: Manchester University, 2006. 
Wormald, J. Scotland: A History. Oxford: Oxford University, 2005. 